\title{
Corporate Social Responsibility (CSR) Business Practices and Stakeholders Considered Relevant for the Energy Sector: The Case of Romania
}

\author{
Buturoaga Cristina Mioara \\ The Bucharest University of Economic Studies, Faculty of Management, Bucharest, Romania \\ dellacheza22@yahoo.com
}

Received date: 27 April 2017; Accepted date: 1 June 2017; Published date: 6 July 2017

Academic Editor: Ştefan Cristian Gherghina

Copyright (C) 2017. Buturoaga Cristina Mioara . Distributed under Creative Commons CC-BY 4.0

\begin{abstract}
The aim of this paper is to investigate corporate social responsibility (CSR) in companies in the energy sector and in the particular context of a European developing country. The results are based on quantitative and qualitative analysis and synthesis and they offer a view of the CSR trends of key companies in the energy sector operating in one region of Romania playing a leading energetic role. In examining CSR, a stakeholder approach is favoured and business activities are recommended. The paper is designed to be of practical use for business decision makers, containing recommendations for them to become more innovative in approaching CSR. Findings suggest that stakeholders are very often unidentified and unengaged, even if they should have the opportunity to encourage companies from the energy sector to take up its responsibilities. This paper contributes to extending previous CSR studies on companies in the energy sector and in a specific context.
\end{abstract}

Keywords: CSR; energy; stakeholders; Romania; developing country

\section{Introduction}

The energy we use is dependent on fossil fuels available in a limited supply (BP, 2015), while its production accounts for two thirds of the world's greenhouse gas emissions (International Energy Agency, 2015b). The European Union has a target of a $40 \%$ reduction of emissions as compared to 1990 levels by 2030 (European Commission, 2014). On a global scale, companies operating in the energy sector face increasing expectations regarding environment (Crane et al, 2014). One of the current social priorities is to limit global warming to less than $2{ }^{\circ} \mathrm{C}$ and these companies are expected to monitor, measure,

Cite this Article as: Buturoaga Cristina Mioara (2017)," Corporate Social Responsibility (CSR) Business Practices and Stakeholders Considered Relevant for the Energy Sector: The Case of Romania", Communications of the IBIMA, Vol. 2017 (2017), Article ID 597300, DOI: 10.5171/2017.597300 
reduce and disclose their greenhouse gas emissions, as well as to bring upon changes in consumer behaviour in order to reduce energy consumption by raising awareness through energy education and by providing them with intelligent solutions for energy management in order to improve climate change. Today, energy is higher priced in the European Union than in the United States and unaffordable for many Europeans (European Commission, 2015a). The price of electricity is projected to grow by 2030 and then to decrease, so companies should design, implement and maintain a customer program to address the challenges they face. The world's population is expected to increase, reaching 9.7 billion in 2050, with an annual growth of $1.18 \%$. In contrast, the population of some countries is projected to decline by more than $15 \%$ by 2050 (United Nations, 2015a). An estimated 1.2 billion people of the world's population in 2013 still have no access to electricity and 2.7 billion rely on traditional energy sources for cooking, with an impact on health (International Energy Agency, 2015a). The world's demand of electricity is expected to almost double by 2050 (European Commission, 2012), even if the development path should be less energyintensive (International Energy Agency, 2014). This rise could also be caused by greater use in heating or cooling, transport, food production, agriculture, etc. To meet this fundamental need of citizens - access to electricity - countries seek to diversify and invest in an energy mix balancing the needs of: security of supply, affordability and production in an environmentally sustainable way. It is fully accepted that the energy will need to come, in the future, from lower emissions sources or from sources with technology solutions developed to capture and store emissions having an important role to play in the $\mathrm{CO}_{2}$ reductions needed to reach net-zero by 2100 .

Companies in the energy sector are sources of direct and indirect jobs and wealth creation for the regions where they operate, but companies also benefit by increasing their image, building their brand trust and ensuring their license to operate. Particularly, in developing countries the wellbeing of the country could be a shared responsibility with companies in the energy sector (Crane et al, 2014). On a global scale, many companies operating in this sector have integrated CSR throughout the organization and some of them are very active in communicating it on their websites, but they also engage with their identified stakeholders and report their performances using internationally recognized initiatives.

In Romania, according to World Bank experts (Romanian National News Agency, 2014) the energy sector contributes with an estimated $70 \%$ to the total of greenhouse gas emissions. Romania has a target to reduce emission by $40 \%$ as compared to 1990 by 2030 (Romanian Department for Energy; 2014). In contrast with other countries, for the population of Romania predictions indicate a $22.1 \%$ decline by 2050 (United Nations, 2015a). According to the World Bank database, in Romania, access to electricity was $100 \%$ in 2012, even if other sources speak about a percentage of 96.3 (Romanian Department for Energy, 2014:473). Also, the percentage of population using solid fuels was $23 \%$ based on 2003 or the latest available data, with carbon dioxide emissions per capita of 4.0 metric tones (World Health Organization, 2006), while in 2011 they were 4.2 per capita metric tonnes as stated by the World Bank database. According to the International Energy Agency (2015b), in 2014, renewable accounted for nearly half of all new power generation globally. In Romania (REN21, 2014), in 2013, solar PV represented 1.1 GW and wind power was represented 0.7 GW. For electric vehicles (EVs), Romania enacted a subsidiary program worth RON 12.000 for the purchase of an EV. According to the same source, Romania has renewable energy targets, regulatory policies and fiscal incentives and public financing: public investment, loans, or grants. The number of power stations is reduced and the EVs are recommended only in urban areas. On a global level, in order to reduce emissions and promote renewable energy, countries have introduced a variety of incentives. According to EY (2014), Romania is ranked 32 out of 40 in a global view on renewable attractiveness which includes Europe, North 
and South America, Middle East and Africa, Asia-Pacific. Final consumption of electricity in Romania declined by $12.5 \%$ in $2008-2013$, while dependence on imports of primary energy represented, in 2013, 18.3\%. (Romanian Department for Energy, 2014:86). According to BP (2015) consumption by fuel in Romania, in 2014 (million tonnes oil equivalent): oil 9.0; natural gas 10.6; coal 5.8; nuclear energy 2.6; hydroelectricity 4.2; renewables 1.4 ; total $=33.7$. Regarding the regulation of energy prices, the elimination of tariffs for the supply of electricity to final consumers ended up on 31.12.2013 for nonhousehold customers and will end on 31.12.2017 for domestic customers (Romanian Department for Energy, 2014). In Romania, most of the capacities for electricity production have exceeded their lifetime, requiring large investments in upgrading and compliance with emission reduction and environmental protection (Romanian Department for Energy, 2014:48). Energy production is achieved mostly in state owned enterprises and renewable energy is at an early stage (Lungu, 2014:166). Romania's objectives include: Romanian electricity market integration in the internal European market; energy security; decarbonisation; energetic efficiency; increasing renewable energy. According to the Romanian Department for Energy (2014), coal will be kept in the energy mix, despite $\mathrm{CO}_{2}$ and $\mathrm{NO}_{\mathrm{x}}$ emissions (Romanian Department for Energy, 2014:65). In 2014, Romania was at the bottom of the innovation performance scale with innovation performance below that of the EU member states' average (European Commission, 2015b:11). Romania joined the European Union in 2007 and is a postcommunist country. According to the World Bank, all low- and middle- income economies are categorized as developing countries, so Romania is a European 'developing country'.

South-West Oltenia Development Region is one of the eight regions of the country and includes five counties: Dolj, Olt, Vâlcea, Gorj, Mehedinți. This region plays the leading energetic role in Romania (South-West Oltenia Regional Development Agency, 2014:213). Energy production comes primarily from two sources: thermo-electric power and hydro-electric power. In Table 1 are presented dates according to South-West Oltenia Regional Development Agency (2014: 212-213).

TABLE 1: Energy features of South-West Oltenia Development Region

\begin{tabular}{|l|l|}
\hline \multicolumn{1}{|c|}{ County } & \multicolumn{1}{c|}{ Energy features } \\
\hline Dolj & $\begin{array}{l}\text {-thermo-electric energy } \\
\text { - exploitation of oil and natural gas }\end{array}$ \\
\hline Olt & $\begin{array}{l}\text {-hydro-electric energy } \\
\text {-oil resources are exploited }\end{array}$ \\
\hline Gorj & $\begin{array}{l}\text {-thermo-electric energy } \\
\text {-extractive industry and exploitation of oil, } \\
\text { natural gas and coal }\end{array}$ \\
\hline Mehedinți & $\begin{array}{l}\text {-hydro-electric energy } \\
\text {-thermo-electric energy }\end{array}$ \\
\hline Vâlcea & $\begin{array}{l}\text {-thermo-electric energy } \\
\text {-hydro-electric energy } \\
\text {-reserves of oil, natural gas and coal are } \\
\text { exploited }\end{array}$ \\
\hline
\end{tabular}

At the end of 2011, across the region electricity was distributed in not more than $96.5 \%$ of homes, under the national average of $96.6 \%$ (South-West Oltenia Regional
Development Agency, 2014:205). Despite its energy role, the region is one of the least developed and is characterized by a GDP per capita below $75 \%$ compared to the EU 
average (South-West Oltenia Regional Development Agency, 2014:8). It contributed in 2011 with as little as $8.05 \%$ of the national GDP and it ranks last among the regions of Romania (South-West Oltenia Regional Development Agency, 2014:255). $48 \%$ of the region's population lives in urban areas. The region ranks last in the country in terms of the average number of employees (South-West Oltenia Regional Development Agency, 2014:93). In 2013, according to the Romanian National Institute of Statistics, age group 1524 year represented only $6 \%$ of the total employed population. The unemployment rate in the region, according to the same source, was $8.7 \%$ at the end of 2013 and the share of the population at risk of poverty or social exclusion was $44.8 \%$, above the national average by $4.5 \%$. In 2011 , birth rate placed the region last on the national ranking and demographic forecasts are bleak for 2025 (South-West Oltenia Regional Development Agency, 2014:62). Transport, communications, business, utility and environment, health, social, emergencies, education, research and development infrastructures are poorly developed according to the same document (South-West Oltenia Regional Development Agency, 2014:461). The region occupies the last place in the country according to the number of SMEs (South-West Oltenia Regional Development Agency, 2014:461).

The concept of CSR has existed, in Romania, since the 1990s (Mandl and Dorr, 2007:12; Romanian Government, 2011:5) and it is still at an early stage (Romanian Government, 2011:5), with actions seen as predominantly philanthropic (Zaharia and Grundey, 2011:202). The private sector is the most active, especially multinationals (Zaharia and Grundey, 2011:197). Social responsibility as equivalent to the term CSR is defined by the Romanian Government (2011:9) as a concept regarding organizations' responsibilities towards society and environment. Since 2011 the first national strategy dedicated to CSR has been implemented, while Romanian Standardization also adopted the international standard ISO 26000:2010 (The National Standardization Body, 2011). At a national level, CSR is a voluntary contribution of businesses, beyond what is required by law.

Previous research in CSR energy sector is conducted on: CSR practices of the Romanian state-owned companies in the energy sector (Buturoaga, 2016); practices disclosure in the Romanian energy sector (Danilet and Mihai, 2013); quality of electricity supply and consumers satisfaction in Romania (Georgescu and Herman, 2014); good CSR practices - Petrom OMV strategy (Dura and Baron, 2015); the analysis of the relation between CSR and energy savings - Asia (Hori et al, 2014), measuring CSR for local communities in mining, oil and gas industries - Indonesia (Prayogo, 2013), extractive industries and forestry practices (Ranangen and Zobel, 2014) and Masdar initiative, in Abu Dhabi, (Mezher et al, 2010).

The need to study CSR in a specific national context is justified as governments approach CSR differently (Crane et al, 2014:492) and, in practice, considerable national variations regarding CSR can be found (Gond et al, 2011:658) but they also differ on a sector level (Crane et al, 2014:14) and even depending on the region where the companies are located (Crane et al, 2014:322).

This paper is motivated by the need for research on CSR in a given sector (CordobaPachon et al, 2014:207), in the energy sector (Buturoaga, 2016), but also in a developing country (Frisko, 2012:217; Jamali, 2008) with different economic, political and sociocultural circumstances, different challenges and interventions needs, outside the developed core (Moon and Shen, 2010).

The question that generated this study was: how do companies in the energy sector approach CSR from the stakeholders' perspective? In examining corporate social responsibility, a stakeholder approach is favoured and its utility sustained through literature review. The aim is to understand how CSR is embedded in a specific context (Dahlshrud, 2008:6) as national variations can be found (Gond et al, 2011:658), in order to identify how it can serve as a development tool (Jamali, 2008). 
The main research question and subquestions, in this study, which shall be answered throughout the investigation, are:

1. Which stakeholders are mentioned by companies operating in the Romanian energy sector?

This question draws on a large body of literature that argues that any company has obligations at least towards: customers; employees; suppliers and community (Smith, 2003:27). Often stakeholders' interests and expectations differ (Sethi, 2003:21). R. Mitchell, B. Agle and D. Wood's offer a theory in order to understand which stakeholders do really count (Mitchell et al, 1997:882) for a company by identifying stakeholders' power, influence and urgency. Clarkson (1995) propose two types of stakeholders: primary and secondary, while Spiller (2000) identifies the primary stakeholders comprising of: shareholders, customers, employees, suppliers, community and environment. The different circumstances in developing countries may change the application of stakeholder theory (Reed, 2002).

2. Is community stakeholder with its important development goals - gender, health and education - in companies' attention?

According to Crane et al. (2014:7), in Europe, healthcare and climate change were recently introduced in companies' strategies. It is appreciated that the European Commission made efforts in promoting equal opportunities for women and men (Pollack and Burton, 2000). Promoting equality of chances for men and women, nondiscrimination and accessibility are cross cutting themes which contribute to fulfilling the Europe 2020 Strategy. Equal opportunity and treatment are promoted through the United Nations, the International Labour Organization, ISO 26000:2010, etc. Utting (Crane et al, 2014:257) appreciates that companies are selective in addressing global principles and standards. He referred to gender equality, which could be omitted from companies' agendas without explanation. Development goals are important aspects of corporate governance and research should offer more attention to them (Hulme et al, 2014). EY (2015) index looks at the number of women in power and utilities leadership positions at the 200 largest utilities companies worldwide and the conclusion is that the energy industry is male dominated. After a financial analysis of these top 200 utilities, the results indicated a correlation between higher gender diversity and higher business performance. It suggested that having more women in leadership roles leads to a better performance. Moreover, approximately $60 \%$ of the global utility industry workforce is over 40 years of age and their knowledge will not be easily transferable to the next generation. Diversity of gender, age, skills and approaches seems to be a vital need in this sector of activity. The World Business Council for Sustainable Development is the institution which reports on the implementation of the Millennium Development Goals (United Nations, 2015b).

3. Is stakeholder engagement at the core of CSR strategies developed by companies operating in the Romanian energy sector?

The academic literature argues that stakeholders' participation is a must (Smith, 2003:29) and that according to Unerman there is no use to report about CSR without their identification and dialogue (Crane et al, 2014:430), as only working with stakeholders' companies could define the opportunities and constrains (Steurer, 2011:3) to understand the larger environment of the company (Coombs and Holladay, 2011:30) and find business solutions. The OECD recommends for state owned companies to be run in a transparent and accountable manner (2015:20) and to respect stakeholders (2015:25), moreover, some of them to report on stakeholder relations (2015:60). Voluntary initiatives in the field of CSR such as: ISO 26000:2010, Global Reporting Initiative (GRI) postulates stakeholder's identification and dialogue.

The article proceeds as follows: first, the literature review presents an overview of CSR outlining how it has been approached into recent empirical studies conducted on the energy sector. The methodology is outlined 
and the proposed stakeholder approach is justified. Several Romanian companies which are operating in the energy sector are examined. The results are discussed and new approaches are proposed. We end with conclusions that answer the main research question, future directions for research and the limits of this study.

\section{Literature Review}

CSR has numerous definitions (Crane et al, 2014:5; Jamali, 2008) even if it has been argued that this effort to define it should be abandoned (Van Marrewijk, 2003:95). The most widely used academic one is the definition offered by Carroll, in 1979 (2012:34) which includes four types of responsibilities for a corporation: economic, legal, ethical, and philanthropic. In 2003, Mark S. Schwartz and Archie B. Carroll (Crane et al, 2014:127) proposed a model based on: economic, legal and ethical responsibilities, which subsumes the initial philanthropic category. But Carroll's pyramid is based on research in the American context (Visser, 2008:488) and reflects Anglo-American circumstances (Crane et al, 2014:68). Visser (2008:265) claims that the order of Carrolls's pyramid levels differs in the context of developing countries where the emphasis is on economic responsibility, followed by philanthropy, and only after legal and ethical responsibilities. Clarkson (1995) claims that Carroll's pyramid is difficult to test in practice. Wood (1991) developed a comprehensive model of corporate social performance focused on the outcomes of CSR but according to Jamali (2008) it suffers from some abstraction. After a detailed analysis of 37 definitions of the CSR, Dahlshrud (2008) constructs a model of five fundamental dimensions: volunteering, stakeholder, social, environmental and economic. The European Commission's Green Paper (2001) definition of the concept advocates that CSR is voluntary, covers social and environmental issues and it is not separated from, but integrated into business strategy and operations. It also looks at how companies interact with internal and external stakeholders. The most influential contribution in CSR is the stakeholder theory
(Crane et al, 2014:135) and the preferred academic definition of a stakeholder is the one offered by Freeman (1984) who changed it over the time (2004). He encourages consideration and management of numerous stakeholders. One of the most famous literature contributions is the one of Donaldson and Preston (1995), who have made a distinction of the three-way approaches: descriptive, instrumental and normative. The theories and principles of the stakeholder concept are known as normative stakeholder theory and are linked to moral principles or philosophical guidelines and should be placed at the core of the stakeholder theory (Donaldson and Preston, 1995). The instrumental stakeholder theory refers to how mangers should act if they wish to work for their own traditional organizational interests. The descriptive stakeholder theory is used to describe and explain how managers work with their stakeholders (Jamali, 2008). Critics such as Freeman (1999) argue that the distinction made by Donaldson and Preston leads to confusion (Reed, 2002). One important contribution to the stakeholder theory is the one of R. Mitchell, B. Agle and D. Wood's (Visser, 2013:114; Crane et al, 2014:137), which offers a theory in order to understand which stakeholder counts (Mitchell et al, 1997:882) because following Freeman's theory literature has identified many stakeholders, sometimes in disagreement (Mitchell et al, 1997:885). The three criteria offered by R. Mitchell, B. Agle and D. Wood's (1997) are: the stakeholder power to affect the firm, the legitimacy of the stakeholders' relationship with the firm and the urgency of the stakeholders' claims towards the firm, but Crane et al. (2014:137) identify shortcomings in this approach. Providing a link between CSR and the energy sector by introducing previous research has a special significance in determining which gaps are and how they can best be addressed. One of the previous research studies on the CSR of companies operating in the energy sector analyzed how CSR is integrated into Romanian state-owned companies (SOCs) (Buturoaga, 2016) and found out that there are problems with the companies' transparency, compliance with the 
law and stakeholders' involvement, as only few responses were analyzed even though the research was conducted on a national representative sample of companies under central public authority. Only one SOC among the respondents has integrated corporate social responsibility. The way it practices CSR is difficult to appreciate because the company answered only part of the questions. Danilet and Mihai (2013) conducted a research study on the disclosure of practices for a sample of 3 Romanian major companies (OMV Petrom, Termoelectrica and Romgaz) operating in the energy sector and stated that the legislation allows interpretation. The study uses 2011 reports and CSR contents available on-line. For the purpose of the analysis, the following elements were used: the presence or absence of a section dedicated to CSR; CSR/ Sustainability report; the identification of CSR topics; CSR contents using J. Ahlering's model. Content analysis of Termoelectrica S.A., the only SOC within their sample, cannot be performed due to the lack of CSR related information. The emphasis of the study is not on stakeholders and related activities. Authors concluded that the analyzed companies are at different CSR development stages. Dura and Baron (2015) present good practices in Romanian CSR of the company OMV Petrom. It is impossible to understand from the text how the authors chose to analyze this company and the reader is not familiarized with the sector addressed by the research. There are no research questions or hypotheses to be demonstrated, but also no limits presented. No comparison with other companies or even with the same practices of the OMV Group in other countries is given. Georgescu's and Herman's research (2014) is dedicated to the relation between CSR and consumers. When studying it, they use information only about one company - S.C. Electrica S.A. - Transylvania subsidiary. It is difficult to understand how researchers have the permission to use a sample consisting of 512 consumers of Electrica S.A and their personal data. This company was privatized, but the State still owns a share of it. In the research conducted by Buturoaga (2016:6), the same company refused to respond to CSR questions. Georgescu's and Herman's article (2014) analyzed 10 questions out of 44 addressed to consumers. Other research studies known by the author when elaborating this study were: Ranangen and Zobel (2014) research, which targets extractive industries and focuses mainly on CSR practices in Africa, Oceania and South America. Findings suggest that community involvement and development, as well as environmental issues, seem to be the focus for mining companies. Hori et al (2014) analyzed the relation between CSR and energy savings through a questionnaire survey in two Asian cities and findings suggest that a positive relation exists between the two, so policies to encourage CSR are recommended. Prayogo's (2013) study examines the method of measuring achievement of CSR using qualitative and quantitative data in Indonesian practice of mining, oil and gas industries. Mezher et al's (2010) research is focused on Masdar initiative, in Abu Dhabi, which has taken leadership in CSR. Considering the above research, the author of this paper has identified the need for additional research to determine how CSR is approached from the stakeholder perspective, which stakeholders count more for the energy sector and the business-related CSR practices to be proposed and followed.

This research is designed to be of practical value to business managers and practitioners by providing them with a view of the Romanian CSR trends, suggested stakeholders to be considered and related practices, to authorities which administer state owned companies in the energy sector, while from the researchers' perspective the study is valuable by addressing a current necessity in CSR, namely the investigation of a particular context, outside the developed core.

\section{Methodology}

The aim of this article is to address the question and sub-questions by using information made publically available on the websites of key companies in the energy sector operating in a region of Romania which plays the leading energetic role (South-West Oltenia Regional Development Agency, 2014:2013). Online investigations were also used by Chaudhri and Wang (2007), Băleanu 
et al (2011) in academic research papers. In the analyzed region, six big energy companies were found, all of them being included in our sample: RAAN, CET Govora, Hidroelectrica, CEOltenia, CEZ, OMV Petrom. Domestic companies seem to dominate the sector, except for: OMV Petrom and CEZ, which are private companies, part of groups of companies from Central Europe and which purchased in the past, one per each, their SOCs established and functional during the communist period with the same business activity. Companies within the sample will be analyzed by being marked with a letter, A, B, C..., according to the order of those stated when we named the companies (Table 2).

TABLE 2: Sample profile

\begin{tabular}{|l|l|}
\hline Company name & \multicolumn{1}{|c|}{ Line of business } \\
\hline Company A & Electricity production in thermo-electric power plants \\
\hline Company B & Electricity production in thermo-electric power plants \\
\hline Company C & Electricity production in hydro-electric power plants \\
\hline Company D & Electricity production in thermo-electric power plants \\
\hline Company E & Electricity distribution and sale \\
\hline Company F & Oil/ natural gas production and exploitation \\
\hline
\end{tabular}

Corruption affecting the public sector in Romania, according to Transparency (2015), scored 46 points in 2015 and it should be noted that some companies do not invest in countries with a corruption risk under 60 points. In order to determine which stakeholders count more for the energy sector, an industry specific understanding of CSR is important (Decker, 2004), so the author had to consider an inventory of international companies operating in the energy sector. A desk research on the latest global trends on a sector level and a study of relevant documentation was performed.

Given the fact that there is no agreed academic definition of CSR, this research will follow a more practical approach based on stakeholder theory, which is the most influential in CSR and which applied to the company level is appreciated to contribute to the rise of corporate economic performance (Donalson and Preston, 1995:87). The research was performed in February 2016. Companies' websites included in our sample were identified, examined and all necessary information extracted. The date of the latest update of each visited website differed from the date when the research was conducted. The author looked for relevant information about CSR or a related terminology, like: social responsibility; sustainability; sponsorship and donations; corporate citizenship; employee volunteering which are often used as synonymous with CSR (Carroll, 2008:38). Following the main question of the article, but also the sub-questions self addressed, in collecting the information from the websites, the author of this research was guided by: a) the company's website section dedicated to CSR: existent or absent; the number and content of subsections dedicated to CSR; the existence or absence of a CSR or a related terminology report and stakeholders consulted; the CSR definition offered; the number and type of standards implemented by the company; b) stakeholders identified by the company: the existence or absence of stakeholders and the order in which they are presented; c) community stakeholder with its development goals - gender, health and education: the existence or absence of references; the content of this statements; d) company's stakeholder engagement: who are those involved and how do they participate? The results were quantitatively and qualitatively processed. This article will operate with the definition given by the European Commission in 2001 where CSR is seen as voluntary, covers social and 
environmental issues, is integrated in the company's strategy which interacts with its own identified stakeholders. CSR is often used synonymously with other terms (Carroll, 2008:38) and sustainability is one of them. A summary of the literature on the sustainability topic will not be provided, as it is beyond the scope of this article. The article uses the sustainability definition given by the World Commission on Environment and Development (1987) and considers that CSR can be part of the company's sustainability, when it adds value to its success (Carroll, 2008).

There are a number of potential problems in using companies' information posted on their websites because such information may have multiple interpretations and may not represent the views of persons in charge. In order to address the limits given by diverse interpretations of the terms: CSR and stakeholders, the author looked for any related terminology. Company involvement, through the answers of the person in charge with CSR, could reveal relevant information, but it was unlikely to receive any answers. Another research (Buturoaga, 2016) was conducted in the Romanian energy sector, but with a focus on state-owned companies, out of which some are targeted by the present research: Hidroelectrica and CEOltenia. In 2015, questions were asked in line with the national legislation (Law 544/2001) regarding free access to information of public interest related to or resulting from the activities of public authorities or institutions, but they were not answered. That research was conducted on a representative sample, on a national level, of SOCs under central public authority. Moreover, one private company within this sample was also the subject of another research based on a questionnaire (Buturoaga, 2014b) where 8 large companies and 8 SMEs were investigated in order to identify the benefits and reasons of integrating CSR and its answer eventually came following a lot of persistence (OMV Petrom). This company provided its answers also regarding CSR reporting and benefits of such an action. Even though this information, which is based on what companies posted on their websites, is limited, it is considered to be more reliable than interviews with persons in charge who can choose from self-serving responses. The research uses publically available information posted on-line, on their websites, by investigated companies. Some limitation may come from the set questions which could be considered preconceived and expected to be in line with the presented theoretical outcomes. The author also sought to explore new phenomena that will not necessarily come under the umbrella of the preset questions. Research on domestic vs. international companies CSR strategies is considered relatively rare (Peng and Pleggenkuhle, 2009). This research will be descriptive, it will offer a view of the CSR trends of the companies in the Romanian energy sector, but will also refer to instrumental and normative strands.

\section{Results}

According to the information posted on their websites, there is no section dedicated to CSR or a related terminology by companies $\mathrm{A}$ and B. Company $\mathrm{C}$ has a section "About us $<$ Social responsibility". Company D has a "Responsibility" section. For company E were found "About us< Social responsibility" and for company $F \quad$ "About $<$ Branding $<$ CSR Campaigns", but also a section dedicated to "Sustainability" and another one for "Sponsorships". So, 4 out of 6 companies have a space on their websites dedicated to CSR.

The number of the sections dedicated to CSR and their content were looked after and noticed that company $\mathrm{C}$ had 3 subsections: "The relation with the community", "Energy for all" and the last one "Corporate Transparency". Accessing the first subsection was found the following: "Volunteering and environmental education" stating that yearly Company C's branches, in partnership with schools, have projects like: symposiums, lectures, visits to hydropower stations, ecological actions and actions for improving awareness regarding environmental importance. No concrete examples were offered. Nothing was said about the results and impact of these projects. It also stated that in 2010 the company organized a painting competition for the employees' 
children. "Social Responsibility projects" described how employees helped the flood victims in a particular region of the country in 2010 by making personal contributions that covered the total reconstruction of 4-5 houses and how the company financed the construction of 4 new houses and the renovation of one school. In addition, money for rebuilding the infrastructure was provided. No data were offered regarding the impact of these actions. Accessing the subsection "Energy for all", historic information about 5 hydropower plants was found and the last subsection "Corporate Transparency" offered sporadic environmental reports (2005; 2009; 2010; 2011-2014). Company D had 5 subsections: "Environment"; "Community"; "Tourism"; "Announcements" and "Contact". The first subsection has the following sections: "Air, water, soil"; "Investments and environmental projects"; "Climatic changes"; Certifications" and "EIM Procedure". According to data published on its website, in "Air, water, soil" section, measures were taken in order to comply with the commitments under the Treaty of Accession of Romania to the European Union, to reduce emissions of $\mathrm{SO}_{2}$ (from $6500 \mathrm{mg} / \mathrm{Nm}^{3}$ at $400 \mathrm{mg} / \mathrm{Nm}^{3}$ ), $\mathrm{NO}_{\mathrm{x}}$ (from $580 \mathrm{mg} / \mathrm{Nm}^{3}$ at less than $500 \mathrm{mg} / \mathrm{Nm}^{3}$ ), dust (from $300 \mathrm{mg} / \mathrm{Nm}^{3}$ at less than $50 \mathrm{mg}$ / $\mathrm{Nm}^{3}$ ), and 11 fixed equipments for monitoring air quality $\left(\mathrm{SO}_{2}, \mathrm{NO}_{\mathrm{x}}\right.$, dust, $\left.\mathrm{CO}\right)$ were mounted in South - West Oltenia Development Region. The website also presents measures undertaken to reduce the noise level and to store waste, in order to comply with Directive 1999/31/EC, for which the company switched to the evacuation technology in dense slurry for 5 of their slug and ash deposits. Modernization measures led to some notable results presented therein and which positively impact on emissions, dust, energy efficiency, water consumption and safety. Company D applied measures to reduce the impact of mining activity and it sustained to have restored the unencumbered land to agricultural and forestry circuit after releasing it from its technological use, as well as its modelling and greening, to comply with the national law. Up to the present, 3.400 ha were given back to the economic circuit. In
June 2015, the company provided a plot of land for reforestation purposes within a project initiated by an association in partnership with the civil society in Gorj County to plant 100.000 trees in 24 hours. No other information was offered. In "Investments and environmental projects" we found desulphurization implementation projects for: Rovinari (2011-2014); Turceni (2011-2012); Craiova II (2015); Ișalnița (2014). A few words are dedicated to present the technology and the impact said to reduce $\mathrm{SO}_{2}$ emissions (from $6000 \mathrm{mg} / \mathrm{Nm}^{3}$ at less than $200 \mathrm{mg} / \mathrm{Nm}^{3}$ ). Projects for slug and ash evacuation in dense slurry were implemented in 4 locations: Rovinari; Turceni, Craiova II, Ișalnița. Other achievements in 2012-2015 period were: $\mathrm{NO}_{\mathrm{x}}$ reduction; restoring two plots of land of 720 ha and 830 ha to the economic circuit. "Climatic changes" section informed that modernization measures bring an increase of the energy efficiency (a reduction in consumption, and $\mathrm{CO}_{2}$ values from $1.05 \mathrm{t} \mathrm{CO}_{2} / \mathrm{MWh}$ produced at $0.910 \mathrm{tCO}_{2}$ /MWh). The website also mentions that, in the process of burning, the company uses biomass combustion resulting from the 10 hectares' plantation, fact considered to reduce the $\mathrm{CO}_{2}$ emissions and to generate income. It was also found out that for 2015 no biomass was used in generating energy and even the company stated that the production of 15 tones/hectare could be obtained 3 years after planting biomass. No data about used biomass were offered for previous years. "Certifications" informed that company D has obtained Integrated Environmental Authorization, Water Management Authorization and Greenhouse Gas Emission Authorization. At "EIM Procedure" there are reports on environmental impact, but only from $04 / 09 / 2015$ to $11 / 09 / 2015$. The subsection "Community" has its own sections, as follows: "Focus on social needs" stating that large amounts were offered to employees because of activity cessation and social benefits for: birth, death, serious illness or as of the result of natural calamities. Company D financed and executed the construction of the water supply systems in Gorj County, affected by its coal mining activity. It still has works in progress in villages: cemetery, water network, 
sewerage system, wastewater treatment plant, dams for river protection - all of them in Gorj County. "Sponsorships" are given for actions such as: educational programs for young people, cultural and sporting activities, as well as for monasteries and exclusively orthodox parishes, located in Gorj County. The company's website displays only the sponsorship list for 2014, following a request coming from the ministry. For 2015, the company announced that they made no sponsorships. "Recommendations" section offers the possibility for website visitors to leave a message. The third subsection "Tourism" informs that the company ranked third for CSR activities falling under "Health" category for projects developed in 2013 within Romanian CSR Awards Gala. The sections found here include: "Săcelu spa resort" where employees can benefit from recreation and medical treatment in this spa located in Gorj County; "Maiami Tg. Jiu Hostel" and "Turceni Hotel", which presents the company's accommodation offer. The last two subsections are "Announcements", offering a long list with links to different announcements and "Contact", displaying the phone and e-mail contacts of two departments: Environment and Tourism. As for company E, its website included a "Social Responsibility" section, but with no content. "Home < Media < Press Releases" displayed announcements about the company's actions, most of them addressed to clients or concerning community involvement. The community-related actions were volunteer projects, sponsorships and partnerships with public institutions and associations: a sport project regarding a martial arts contest for children aged 6-12 years; a marathon where the money collected from participation fees is to be used to equip a paediatric department of a hospital from South-West Oltenia Development Region; the electrician's trophy with 69 children enrolled in the competition and 12 finalists; collaboration with an association in order to provide support for the screening of a documentary film and discussions about human rights in schools held during one week per year; a pilot program for electricians in 2016-2017, dedicated to $8^{\text {th }}$ grade-students offering the possibility to obtain monthly scholarships, mentoring and access to equipped laboratories; international festival of poetry; support in the organization of national English Olympiad for high school classes; international theatre festival; internships for university students both in technical and economic studies; acquisition and supply of medical equipment for a paediatric department of an emergency hospital in the South-West Oltenia Development Region; organizing tree planting in partnership with forest districts, students and the company's own employees, etc. The posted information refers to the company's CSR strategy whose main lines of action are: education, health, culture and sports. Company $\mathrm{F}$ had a dedicated section - "Sustainability", one "About<Sponsorships projects" and another one "About<Branding $<$ CSR Campaigns". The research concentrated on the section "CSR Campaigns", where an archive with results from 2007-2013 could be found. In 2007, the company addressed the problem of lack of green spaces and invested in rehabilitation and construction of some parks. These are not localized in the region analyzed in this article. In 2008, the company worked in publicprivate partnership with other institutions and supported the enrichment of the forest land in Romania by offering financial support and volunteers among the company's employees. No further information was provided. In 2009, within the same forestation program, the company developed an awareness campaign. It is also mentioned that in 2 years 65 hectares were planted with the help of 26.000 volunteers. In 2010, a national contest on eco-civic themes for students and their teachers took place and within this contest 3 proposed plans were financed by company F. This CSR project continues yearly, and a dedicated website being created for this. Other information was not provided. In 2011, the company developed a website where Romanians could propose a hero in the national health system, then a contest was held and 3 doctors received specialized scholarships abroad. In 2012 and 2013, the company continued the project started in 2010 to sustain social entrepreneurship. "CSR Campaigns" contains two dedicated sections about company's F CSR projects: "Rediscover Romania" and "Andrei's Country", both of 
which lead to a dedicated website. Following the visit of the first website, it was found out that in 2010, for 3 months, 4 teams travelled across the country and drew a map with more than 800 recommendations to be visited. In 2011, 5 trips were organized in partnership in order to complete the existent map with other national touristic destinations. The second website, "Andrei's Country", is a CSR project, available from 2009. It has 7 main sections. The first one presents the mission of the project. The second one presents examples of people and their projects implemented with the financial support offered by company F. "Professional Romania" is a campaign through which vocational education is sustained. In 2015, a school of oil-industry workers was held, for the first time, in partnership with 3 technologic high schools from Moinești, Târgoviște and Pitești cities, which are outside the analyzed region. There were 3 classes with a total of 84 students. Company $\mathrm{F}$ invested in the refurbishment of 1 school class, 2 laboratories and offered 84 monthly scholarships (700 lei/ person). In 2015, as well as in previous years, in partnership, a one-week camp was organized where 200 children and 40 teachers from Prahova County participated in workshops for personal and professional development. The following occupations were promoted: hairdresser, tailor, cook, auto mechanic and well operator. 20 children received a scholarship (500 lei during 2015-2016 school year). Teachers received training and laptops. Prahova County is part of another region of the country. In 2015, a study of perception and analysis of labour market was conducted by company $F$. In the same year, they organized a debate on vocational and technical educational system. The section "Made in Andrei's Country" is a social entrepreneurship competition, sustained in partnership with an NGO. There were 2 editions (2013 and 2015) and each time 10 projects were financed. "Ideas from Andrei's Country" is a national competition through which the company supports sustainable initiatives in areas such as: vocational education and environment. This competition was held beginning with 2013. 19 projects were financed in 2015. Section "CERC
Boldești-Scăeni" is a program started in partnership in 2012 for the development of a particular community through education: afterschool for 60 children and afterschool activities for 100; parental courses for 100 persons; 22 adults completed their studies. This program is dedicated especially to the Roma community which represents $10 \%$ of the city population. Boldești-Scăeni is outside the South-West Oltenia Development Region. Analyzing another section of the website "Andrei's Country", reports for community involvement (2012-2015) were found and activities such as can be added: 100 youth, aged 14-18 years old, from across the country, participated for two days in free leadership, communication, personal development and entrepreneurship programs (no other information were offered); a one-week summer school, where some national and international speakers were invited; 4 MBA students and 11 students were sustained by company $\mathrm{F}$ through scholarships; 11 public schools and their laboratories were refurbished; 7 public health institutions were refurbished and equipped. Company $\mathrm{F}$ presents sponsorships offered to sustain gymnastic national team, ski federation and other competitions. The company's employees were involved in volunteering since 2007. Only dates from 2011 and 2012 were found. 10 projects initiated by employees were financed as well by the company in 2015 in a competition of volunteering for projects supporting communities. Employees could engage in many other voluntary actions and one of them was to offer presents to children, in 2008, for Christmas. Regarding environment protection, it is mentioned that: 10.800 persons were trained; one beach was cleaned up; 77 monitoring actions for the dolphins in the Black Sea were performed with company's support. No other information was offered related to a special interest of the company in such actions. Company $\mathrm{F}$ had health and hygiene campaigns and they also provided courses dedicated to Internet security for children. In total, 1.100 children and 1.000 women were trained. 4.300 students, teachers and parents received training for the prevention of emergency situations. No other 
information was offered regarding to which communities these persons belong, when were they trained, the duration of this training and any feedback received. Old CSR projects are also presented in this section of the website regarding the company's involvement. One of these projects was held during 2007, 2008 and 2009, when 6 parks were created or refurbished. None of the parks are placed in the South-West Oltenia region. In partnership with the National Health Ministry, in 2010, company F supported the extension of national telemedicine network for 19 counties and 59 public hospitals. It offered 3 ambulances and 3 specialized scholarships for 3 doctors. In 2007 sponsorships worth 1.2 million euro were offered in order to increase the efficiency of the intervention team of the General Inspectorate for Emergency Situations. In 2007 and 2008, company F built over 176 homes in partnership with the National Government. These houses are not located in the analyzed region. Between 2009 and 2010 more than 1.500 children and teachers benefited from education for the prevention of emergency situations. For one of these projects company $\mathrm{F}$ invested 70.000 euro to train 600 children in 6 schools in the capital of the country in order to learn how to react in case of earthquake. During 2010,
2011 and 2012, company F planted trees. Of all planting actions we found, in 2010, Mârșani locality as part of the analyzed region. In 2012, the company planted 102.500 trees on 16 hectares with 2.250 volunteers and spent 300.000 euro for very young trees. In 2009, 600.000 euro were spent by the company to refurbish 4 public schools in which a total of 184 children learnt (41 among them were the company's own employees' children). In the same year, the company drilled 3 deep water wells in three municipalities of South-West Oltenia Development Region, spending 70.000 euro for this project. The website mentions that a total of 2.500 Olympics contests were supported by company F. No further information concerning the Olympics or the way the company chose to support them is provided.

Ratings of CSR actions are presented in Table 3 , using a binary representation (with the items looked for on one axis and on the other with companies within the sample), with one in case of data availability on company public website, or zero otherwise. These ratings report only the findings based on the dates presented by companies on their websites. The total score obtained in this table by a company cannot be used as a measure of the overall CSR performance of that business.

TABLE 3: Numeric ratings for each item the research was guided for

\begin{tabular}{|l|l|l|l|l|l|l|}
\hline Item Company & A & B & C & D & E & F \\
\hline CSR section and subsections & 0 & 0 & 1 & 1 & 1 & 1 \\
\hline CSR report and stakeholders consulted & 0 & 0 & 0 & 0 & 0 & 1 \\
\hline CSR definition & 0 & 0 & 1 & 1 & 0 & 0 \\
\hline Standards implemented & 1 & 1 & 1 & 1 & 1 & 1 \\
\hline Stakeholders identification & 0 & 0 & 0 & 0 & 0 & 1 \\
\hline $\begin{array}{l}\text { Actions regarding community } \\
\text { stakeholder goals - gender, health, } \\
\text { education }\end{array}$ & 0 & 0 & 1 & 1 & 1 & 1 \\
\hline Stakeholders engagement & 0 & 0 & 0 & 0 & 0 & 1 \\
\hline
\end{tabular}


Out of 4 companies whose websites include sections dedicated to CSR, only 1, company F, has a "Sustainability Report", dating from 2011. The last report, from 2014, is GRI G4 and is displayed on the website. The following groups have been identified as key stakeholders for reporting: academic and research institutions; authorities; business partners; competitors; customers; industry associations/networks; local communities; media; NGOs/NPOs; employees; shareholders/capital markets; society; suppliers and contractors. Stakeholders' prioritizing has been made using a matrix based on their power and interest. There are regular interactions with the company's stakeholders, varying from several times per month to once a year. To address GRI G4 requirements, in 2014 the company led a dialogue with internal and external key stakeholder groups: employees, business partners, clients, suppliers, associations and consultants, NGOs, universities, banks and authorities. A stakeholder consultation and materiality process was held in 2014, during which material issues were ranked as follows: high importance (health and safety; oil spill; security; business ethics and corruption; energy efficiency; regulatory environment; employee attraction, retention and training; impacts of climate change; governance; community engagement; diversity; human rights), moderate importance (water management; renewable energy; supply chain management; research and development) and low importance (unconventional energy sources; biodiversity). Stakeholders consulted included: financial and SRI analysts; NGOs; suppliers and contractors; regulators; business leaders; universities and research institutes; customers; local authorities; the company's employees.

Only 2 companies defined CSR on their websites: company $\mathrm{C}$ defined it as an action, the help provided to those in special situations, involvement; company D defined it in relation with environmental protection and its involvement in local communities where it is present.
Regarding the number and standards implemented by companies: companies A, C, D, E, F had: ISO 9001; ISO 14001; OHSAS 18001, while company B had ISO 9001; ISO 14001. Company F had also: ISO 50001 Energy Management System; Beginning with 2013 the company became affiliated to the UNGC and WEP platforms, and from 2015 to the local Global Compact Romania.

Stakeholders were identified only by company F, which also offers a map of these groups. Stakeholder groups include: business partners; employees; capital market; professional and employee associations; media; bank institutions; NGO/ NPO; market competition; central administration; local community; research/ science. Stakeholders groups are then named, but they are not ranked taking into consideration their relevance to the company.

The community stakeholder with its development goals - gender, health and education - is taken into consideration by: company $\mathrm{C}$, but only for education, as its website states that the company had yearly projects in partnership with schools to raise awareness regarding environmental importance (no further information was offered); company D, which supported education and health through sponsorships offered only in 2014 ( 3 sponsorships out of 38 were offered for education); company E, which seems to have considered only health and education; and company F, which provided information on all three goals, stating that it has a diversity strategy by setting an objective to attain a mix of $30 \%$ females and 50\% internationals until 2020 at Senior Vice President group level. Company F has also implemented an Antidiscrimination Directive. In 2011, the company made an internal study about gender diversity. Health and education were also considered by the company $\mathrm{F}$ through many actions already presented in this section by the researcher.

Stakeholders engaged by company $\mathrm{F}$ are those considered relevant for each project. The company has developed beginning with 2011 
an internal data base to help their employees in identifying the relevant stakeholders. Its website states that stakeholders participated in discussions regarding their needs and viewpoints and interactions were formalized. Company $\mathrm{F}$ has organized an annual stakeholders' forum beginning with 2009. Regarding the dialogue of the company with its stakeholders, we found out, from company website, that 170 representatives of national local authorities of the communities in which the company has operations had the possibility to participate, for 2 consecutive years (2013-2014), benefiting from the financial support of company $F$, in an entrepreneurship education project and to learn how to draw up projects to access European funds. Also as part of its dialogue with the civil society, the company held a meeting with 24 NGOs in 2014. In 2011, 2012, 2013, the company organized fairs in which over 90 NGOs participated, in order to obtain the financial employees' support. In 2015, 250 NGOs representing the civil society were supported by company F's redirecting $2 \%$ of the income tax of its employees. 10 community resource centres were created with company F's support (188.000 euro for community projects) where the company's representatives, local authorities and local community hold monthly meetings. The information on community relations annual plans for each of these centres and on the stakeholders consulted and involved could not be found. No further information related to stakeholders was found on the other company's websites.

\section{Discussions}

It can be argued that CSR should not interfere with profitability (Crane et al, 2014), but that it should be voluntarily integrated by any company into its strategy (Galbreath, 2006). Five companies, 4 of which are SOCs, disclose no information on their websites regarding the stakeholders they manage, and provide no information regarding identification, prioritization, interaction, and engagement with them. The OECD (2015:25) recommends that state-owned companies fully recognize their responsibilities towards stakeholders and in some cases report on relations with them. In addition, the Romanian National Strategy to Promote Social Responsibility 2011-2016 states that SOCs must actively apply social responsibility starting with the choice of their suppliers, and that, if necessary, administrative councils will be changed if they do not pay enough attention to applying social responsibility (Romanian Government, 2011:28). The results obtained through this research could mean that soft legislation is not always applicable. All six companies analyzed date from the communist period, when there were no constraints regarding agreements with residents or public consultations, and there were few environmental obligations to be respected. Moreover, almost all land, even private land, became State property. During communism, companies were non-legitimate (Reed, 2002), but now they should operate without benefiting from historic injustices (Reed, 2002). Citizen participation is a process that should take part in stages, firstly to inform, secondly to consult, and finally to involve. In the informing stage, one should make use of as many techniques depending on being addressed. Accordingly, it is unlikely that many people in a community with weak communication infrastructure, high levels of unemployment, a high number of elderly people, and a population at risk of social exclusion (South-West Oltenia Regional Development Agency, 2014), will pay attention to announcements on websites or purchase a particular local newspaper on a particular day (ex. Company D, 27/03/2013) in which an announcement by an energy company is published, and therefore be aware of and exercise their rights to participation in decision making. In addition, being informed involves educating the public and increasing awareness. In the public consultation stage, groups of citizens should be convened from geographical areas directly impacted by the operations of a company in the immediate vicinity, rather than an announcement being posted at the village mayor's office, which may be located a long distance away. To obtain the formal environmental agreement to increase the stability of the slag and ash deposit in Valea Mănăstirii (Company D), no interested members of the public were present at the public debate meeting, which 
was not a concern for the authorities and the company (Romanian Agency for Environment Protection - APM Dolj, 2013). They were not invited and did not attend NGOs. The legitimate procedural framework is observed (carrying out the procedure established by Law no. 52/2003 regarding the decisional transparency), but the way the participatory process is carried out could continue to further weaken public confidence in public authorities and companies. The access to public information for people with disabilities, by virtue of the principle of equality of rights of all citizens, cannot be assured given that accessibility measures in the information and communications technology (ICT) sector have not yet been practically implemented. Individual notification by mail of the population and landowners in the immediate vicinity would be more realistic, while for the remaining citizens measures already provided for in the law should be applied. The delays established by law from the date of the ad publication until the public debate with a view to decision making are too tight given that it takes several public meetings and consultations with citizens that should be organized right next to the site for which the legislation drafting is requested. Regarding participation in the decision-making process, special invitation of the population and landowners, as well as legally established associations near the state company site should be mandatory. Those among the population and landowners in the vicinity of the site who have belonged for generations to the host community should have the opportunity, separately, to intervene to make recommendations during public meetings conducted. Public authorities should draw up an annual report on their own decisional transparency, broken down by each action, which should include the evaluation carried out by those who participated in the meetings. The report should be made public by posting on the site of the authority, but also on the site of the company for which the piece of legislation was drafted.

The community stakeholder with fewer resources has little influence and less sense of urgency, but provides operating legitimacy.
Citizens should have more opportunities to exercise their rights as well as the rights of future generations or the collective rights of minorities and those who have belonged for generations to the community neighboring traditional large utility business' operations. Company F consulted with NGOs in 2014 as part of the dialogue with the civil society, but do not forget that the company has facilitated, to almost 90 NGOs, the support from its employees, consisting of $2 \%$ of the income tax. In 2015, 250 NGOs were supported in this way. Consultations should be held with the people and landowners who neighbour the company's operations and broadly with the community host, while, naturally, local authorities could take part in these consultations. A priority of the company should be the suggestions made by neighbours, people and landowners, as well as by those who have belonged to the host community for generations and neighbour the company's operations. In South-West Oltenia Development Region, there are only a few small local civil society organizations. Due to the lack of local community groups in the communities in which company $\mathrm{F}$ operates, it invested financially, as it sustains, in setting them up. Moreover, it invested in training 170 representatives from national local authorities from the communities, and with 188.000 euro for community projects which include activities such as: cultural events, sports, environmental protection, non-formal education, career guidance for young people and qualification training. However, as the training mentioned is not supported by any additional information, it could also mean that, for example, all qualification training is provided for a particular community and not for every community in which the company operates. This also raises the question of what is meant by qualification training and how many benefitted. The effects of undertaken activities by company $\mathrm{F}$ are not tracked. For example, briefings should be provided on the number of people from the host community who benefited from courses and that were hired or on reducing the number of cut trees or on the amount of generated waste, etc. This kind of relationship with the particular host community may further weaken confidence as 
it could be possible for a company to make use of its influence in order to receive necessary monthly or annual documentary evidence which could prove their involvement and legitimacy to operate from the unique civil society existing in that particular community and created only with the company's support.

CSR information disclosed by Company C relates to employee and company donations for a particular community. Indeed, the supported cause relates to the company's core business. For the educational projects initiated, the company should have provided detailed information regarding the studies conducted in order to identify the usefulness of such action, dialogue and consultation with its stakeholders, schools which participated, numbers of children, grades, and a detailed description of the action implemented and its impact.

Environmental measures presented by company D are taken in order to comply with the law, as stated, and could not be considered CSR actions. According to research by Gavrilescu et al. (2013), measurements carried out in April 2012, in the industrial zone CET I (Company D), reveal a significant content of particulate matters with a value of $66,3 \mu \mathrm{g} / \mathrm{m} 3$, which exceeds the limit set by $32.6 \%$. Also, on hourly measurements made at CET I, on $05 / 04 / 2012$, the maximum values recorded exceeded the limit by $183 \%$ and 253.8\%. No details were given about the company's D equipment for monitoring air quality. Nearby population and small landowners affected in this region have no access to equipment to carry out measurements in order to prove companies' failure to comply with legislation. It is imperative for a high degree of transparency that functional stations are installed where information can be displayed, in real time, regarding values of major pollutants measured near stations and ash landfills which everyone has access to. The community should be educated about the full range of firms' activities, and have access in real time to environmental data (Lyon and Maxwell, 2006). If we consider that Company D ranked third for CSR activities falling under "Health" category, it is discouraging and sends a wrong message about CSR best practices to be followed in the energy sector. The company disclosed no information regarding their GHG emissions derived from the use of coal transportation taking into consideration that in the city of Craiova the company burns coal transported from another city. The resultant ash is stored near the city, without the agreement of the nearby population and landowners from the immediate vicinity (Romanian Agency for Environment Protection - APM Dolj, 2013). Company D stated it burned biomass resulting from its 10 hectares cultivated. The total annual amount of biomass produced should be reported, in addition to information regarding the crop, if it is managed in a sustainable manner, and even if the company complies with international standards. In 2015, as indicated by the company, the energy produced had a 0.00 biomass in composition, while coal was $99.08 \%$, with $\mathrm{CO}_{2}$ emissions of $887 \mathrm{~g} / \mathrm{KWh}$ above sector level (292.02 g/KWh) even with all the upgrading done on all its operation installations. On the company's website, information should also be provided regarding emissions for all years since its establishment and not only for 2015. The company should report all information to stakeholders relating to the sources of water used for their activities. No information is provided regarding those sources and their impact, even if water should be used responsibly given its affected availability for the future. Actions such as constructing water supply systems for those affected by the company's coal mining activities do not qualify as a CSR activity. Moreover, explicit details should be made available regarding this event, how the company was penalized by the authorities, and how it will manage undesirable outcomes to prevent them in future. Only the sponsorship list for 2014 was published by the company as an obligation, even if it had sponsorships in previous years. As Company D is a SOC, it should have published all years since its establishment. There are no details of how projects supported by sponsorship were chosen, or of how stakeholders were engaged. Through sponsorships, the company discriminates against other religious faiths of people from 
the communities in which the company operates, and its CSR actions should not be limited to the county of Gorj. The risks a firm like company D faces are: violation of human rights, environmental standards and biodiversity threats for biomass. The firm should address these risks with priority, as well as communicate them. No information was provided about assuming the extended responsibility in the supply chain and its associated risks that should be prevented by the existence of some common requests imposed on its own contractors and subcontractors.

Based on the information provided by the SOCs (company C and company D) analysed, we can conclude that they do not understand CSR, and present philanthropic actions on their websites as representative of their CSR policy. This is supported by research conducted by Buturoaga (2016), who found in a study of a representative sample of SOCs under central public authority in 2015, that only one SOC out of six having responded identified its stakeholders, less: consumers, the environment, contractors. Of the other 5 SOCs, two of them answered "that is not the case"; the other 3 did not answer the question. Philanthropic donations leave the company unaffected (Crane et al, 2014) and reflect only the managers' interest and opinions (Porter and Kramer, 2002:2). CSR is about stakeholder engagement and management, in order to address their needs and concerns (Werther and Chandler, 2006:285).

Company $\mathrm{E}$ discloses no information on its website regarding the stakeholders it manages. It seems that company $\mathrm{E}$ is trying to build a reputation (Healy et al., 1999:162) based on donations and being a supporter of education, culture and sports in the analyzed region. Company $\mathrm{F}$ discloses and reports according to GRI G4 information on stakeholder management. There is no information on the community stakeholder relating to the major dialogue with key stakeholders held in 2014, in Bucharest. As for the consultation and materiality analysis in 2014 , the community stakeholder cannot be identified through the stakeholders consulted, a fact which explains the low importance Biodiversity received when topics were ranked. For companies operating in the energy sector, the host communities, population and landowners in the vicinity of the companies' operations, should represent a key stakeholder and should be consulted and engaged. Annual plans for each of the host communities and surveys carried out in order to identify the needs and to define plans should also be set out. Company F's CSR actions are focused particularly on urban areas, although the company also operates in rural areas. One hypothesis which could be derived from this is that by investing in the community the company is focusing on urban consumers because of image benefits, brand trust improvement, profit from increased consumption and sales (strategic motivation), and to prevent formal governmental intervention which could be requested by educated and vocal stakeholders (political motivation). Rural communities have different cultural values and norms, as well as less power to influence the government (Reed, 2002) compared to urban citizens, especially those from prosperous economic cities. In terms of gender diversity in the South-West Oltenia Development Region in 2011, 10.163 men and only 2.813 women worked in the production and supply of electricity, gas, steam and air conditioning (South-West Oltenia Regional Development Agency, 2014:94). This means that energy sector companies which operate in the region analyzed continue to support the perpetuation of circumstances that generate injustices to women. Some of the activities undertaken by company $\mathrm{F}$, like strengthening the capacity of public authorities, improving school infrastructure, building houses, and improving health infrastructure are Government responsibilities (Crane et al, 2014) and perhaps the fact that companies have been encouraged to assume such responsibilities prevents them from approaching CSR strategies using their skills and competencies to develop broader public goals and improve the competitive context (Porter and Kramer, 2002:3) which would develop the local region as well as offer the 
company a new market to operate and the opportunity to innovate and find new ideas and technologies in the energy sector. Insufficient information is provided by company $\mathrm{F}$ about the forestation program. Regarding the refurbishing and re-equipping of 11 public schools and 7 public health institutions, no explicit details are provided regarding stakeholder dialogue and consultation, which schools and health public institutions received financial assistance, who the final beneficiaries were, how long the process was, how much the company invested, and any impact or feedback. There is also insufficient information regarding how the company chose the children and teachers who participated in their organized camp in 2015, and why such occupations as hairdresser, tailor, cook, auto mechanic were promoted when the company operates and has expertise in the energy sector. Questions could be raised about numerous courses held by the company in the field of: social entrepreneurship, leadership, communication, personal development, and entrepreneurship programs. The Romanian Government, through European nonrefundable funds, offers such courses to different communities all over the country. The real challenge is to provide jobs, especially to young people. Indeed, company $\mathrm{F}$ offered employment opportunities through financial support and expert advice for the establishment of social entrepreneurship which, above all, creates social value (Crane et al, 2014). It is appreciated that the company's effort is to improve the local context otherwise it has no key competences in this field. The impact of such activities should also be measured by considering how many jobs were created in each new company and how many have been retained over time, how many new companies have formed clusters or continue to exist after 3-5 years, and how many have been developed and internationalized. Gender diversity could also be integrated into policies and practices for contractors and subcontractors. No information could be found regarding training offered by companies from the energy sector to develop small businesses or individuals in the host communities so that they can become a contractor or supplier. Likewise, there is no information regarding encouragement for local procurement. No details are offered by company $\mathrm{F}$ about how it chose who received presents at Christmas, nor about the schools which participated in the project through which children from the capital received training to learn about how to react in the event of an earthquake, or about how company F supported 2500 Olympics. Some important contributions for CSR activities (3 million euro) from company $\mathrm{F}$ were made in partnership with some public institutions, between 2007 and 2012. This raises the question of whether these contributions were made to prevent formal government intervention (political motivation) or for an influence in the market (strategic motivation), given the fact that companies' CSR activities should be correlated to the business core competences. What is the real benefit of the firm from such an action? Cooperation between two partners only puts the emphasis on the company. On the one hand, one could consider that the company solved an important issue of its partner in need. On the other hand, it could increase visibility and induce a positive assessment of the company, related to its nationwide influence, seen as equal to that of its partner that functions as a guarantor, discouraging stakeholders and host communities to raise their concerns. Actions such as planting 102.500 trees with 2.250 volunteers at a cost of 300.000 euro, or 600 children, from the same city, trained to react in the event of earthquake with 70.000 euro, and 4 state schools with a total of only 180 children refurbished at a cost of 600.000 euro. These actions look inefficient as they are so costly. The company is not a public authority, and therefore cannot be held accountable (Matten and Crane, 2003) as it is within its rights to organize its social activities as it sees fit, no matter how correct they may or may not seem. Moreover, the information provided on CSR activities is discretionary, as no companies are obliged to integrate or to disclose information about it. The Romanian Government through its national CSR framework has also failed to indicate activities to be carried out by companies. The two private companies in the energy sector have recently started to select projects to transfer their skills and competences. In 
2016-2017, Company E selected the school for electricians' pilot program and internships for university technical and economic students. Company $F$ selected the school for oil workers, the first in 2015-2016 and internships. Although both private companies also embrace long-term CSR strategies, which will benefit society but also the company, only company $\mathrm{F}$ does so in consultation with stakeholders. However, stakeholders' identification and management is appreciated by other researchers to be done in order to reduce the risks of negative regulatory actions (Bird et al, 2007; Ioannou and Serafeim, 2015). It is appreciated that the social innovation approached by company $\mathrm{F}$ in building a passive house at Boldești-Scăeni does not lead to opportunities for development of new ideas and technologies in the field of energy, which would serve communities in the long term (Crane et al, 2014:557). An example would be the Smart Region Pellworm (company E.on was one of the partners) where stakeholders and organizations networked together in order to achieve innovative new solutions in the energy field.

In the event of exceeding national agreements regarding emissions, companies from the energy sector, which do not engage on health aspects with the host community they neighbor, should provide health screenings for host communities as well as compensation rather than be required to pay monetary fines which will not address potential health problems and risks to those impacted. Some companies from the energy sector invest in health care which they consider important for society at large without consulting their host communities. One other obligation that companies from the energy sector should have is to educate host communities about biodiversity, energy conservation and safety, clean transport, production technologies and green energy. Multiple channels should be used to keep communities informed about the company's activities.

But why such heterogeneity among companies in terms of their CSR regarding stakeholders? Based on the facts previously presented, this heterogeneity may mean that the operations of a company in the energy sector could be carried out without the need and obligation to engage and report to stakeholders, or to obtain host community permission, but it also speaks about the local moral practice/ norms and values of the society (Crane et al, 2014:84) in which it operates and about the context of operations which influence the type of CSR (Crane et al, 2014:449). For any of the analysed companies, there is little stakeholder pressure. We can conclude that the companies in the Romanian energy sector could consider host communities only if this will help them improve their reputation and brand image (strategic motivation) or, less credible, out of ethical considerations, or in order to report under GRI standards, which supposes stakeholders' identification and consultation. Reporting could be done out of ethical, economic or political reasons. Within the liberal view, the State has the responsibility to fulfil individual citizens' rights, while companies only have to respect those rights (Matten and Crane, 2003). The States encouraged or induced and transferred their duties to companies, but they cannot be held responsible for their actions (Matten and Crane, 2003). Businesses are less likely to provide the needed funds to protect current and future citizens' social rights. Moreover, being interested in shifting away from some of its responsibilities (Moon, 2004), the State could sacrifice its citizens' rights and intentionally neglect or postpone formal governmental interventions on companies. CSR policies strongly depend on the national context. Moreover, self-regulation of companies, especially the one of SOCs, operating in a protected environment, does not always work (Crane et al, 2014:489). Selfregulatory approach depends on some conditions which must be fulfilled (Reed, 2002). Taking into consideration that, in Romania, CSR is left in the hands of corporations, with a lack of coordination on the part of the national CSR framework, also there is little stakeholder pressure, philanthropic contributions to society would persist (Buturoaga 2016). On an international level, there are no mandatory standards for the consideration of varying stakeholders' 
interests (Reed, 2002). A European framework for CSR was not favourably received (Moon, 2004). There is no universal model of CSR (Monks and Minow, 2004:298). Deva (2006) argues that the ten principles of CSR declared by the United Nations are abstract in practice. Companies have different values and resources (Porter and Kramer, 2002) and the way in which CSR is implemented even on a sector level differs and tends to be affected by many variables (Aquilera et al, 2006:148). CSR must remain voluntary (Visser, 2013), but the State should protect the interests and concerns of different stakeholders' groups fact that requires a regulatory approach (Reed, 2002).

Indeed, the discussions bring forth CSR practices of companies which are active in this regard. The statements and ratings presented report the findings based on the information found on companies' websites. Table 4 offers recommendations for each company.

\section{TABLE 4: Key recommendations for each analyzed company}

\begin{tabular}{|c|c|}
\hline Company name & Key recommendations \\
\hline Company A & $\begin{array}{l}\text {-integrate CSR into the strategy; } \\
\text {-disclose information about CSR activities. }\end{array}$ \\
\hline Company B & $\begin{array}{l}\text {-integrate CSR into the strategy; } \\
\text {-disclose information about CSR activities. }\end{array}$ \\
\hline Company C & $\begin{array}{l}\text {-continue implementing CSR activities; } \\
\text {-offer up-to-date CSR information on the website; } \\
\text {-identify, prioritize, interact and engage with stakeholders; } \\
\text {-conduct studies and analysis before choosing a CSR activity; } \\
\text {-disclose detailed information regarding the CSR activities; } \\
\text {-track the effects of the CSR activities; } \\
\text {-consider reporting. }\end{array}$ \\
\hline Company D & $\begin{array}{l}\text { - continue addressing health and education; } \\
\text { - respect different stakeholders' interests; } \\
\text { - honour ethical value; } \\
\text { - address diversity; } \\
\text { - offer up-to-date CSR information on the website; } \\
\text { - provide information about CSR in the supply chain; } \\
\text { - disclose detailed information regarding the projects supported } \\
\text { through sponsorships; } \\
\text { - disclose detailed information regarding the sources of water used; } \\
\text { - provide information on all GHG emissions; } \\
\text { - set out annual CSR plans for each host community; } \\
\text { - use skills and key competencies; } \\
\text { - identify, prioritize, interact and engage with stakeholders; } \\
\text { - display in real time information about air quality near each power } \\
\text { stations and landfills of slag and ash to which everyone has access } \\
\text { to; } \\
\text { - consider public consultations with the particular host communities } \\
\text { who neighbour companies' operations and obtain their agreement; } \\
\text { - consider reporting. }\end{array}$ \\
\hline Company E & $\begin{array}{l}\text {-offer information in the dedicated CSR section on the website; } \\
\text {-disclose detailed information regarding the CSR activities; } \\
\text {-continue addressing health and education; } \\
\text {-continue using skills and key competencies; } \\
\text {-consider reporting. }\end{array}$ \\
\hline
\end{tabular}




\begin{tabular}{|l|l|}
\hline Company F & -continue addressing diversity, health and education; \\
& -continue using skills and key competencies; \\
& -disclose annual plans for each host community; \\
& -engage with community stakeholders, prioritizing the ones who \\
& neighbour company operations and the ones who have belonged to \\
& the host community for generations; \\
& -disclose the effects of each CSR actions; \\
& -provide all the information supported by necessary details, for \\
& anybody to understand the process; \\
& -provide information about CSR in the supply chain; \\
-choose partnerships with more private companies.
\end{tabular}

But who are the main stakeholders to whom a company in the energy sector should be accountable and which are the responsibilities it should fulfil? The usefulness of a stakeholder approach is legitimized by the results obtained through this research, but also by other studies conducted in the Romanian energy sector that were presented in the introduction of this article. In an empirical research on companies in different industries, Jamali (2008) using Spiller (2000) identifies the primary stakeholders comprising of: shareholders, customers, employees, suppliers, community and environment. Following the inventory made by the author of the international companies, these six main stakeholder groups are considered suitable for the Romanian energy sector as well and based on this categorization the research is going to offer recommendations to be also considered by the analysed companies. Managers will not be provided with a CSR guide, but rather offered suggestions regarding the various stakeholders considered relevant for the energy sector. The assumed responsibilities are justified by the need for an ethical operation and market interests (image, reputation or corporate governance gains). There could be variations in corporate approach according to national, industry and company specific factors. These recommendations are not exhaustive and can be extended to incorporate specific industry aspects. Measuring CSR costs and benefits for stakeholders is vital.

\section{Stakeholder: shareholders}

CSR Business practices: Shareholders should receive attractive total shareholder returns, responsible long-term business strategy execution, ethical behaviour, well managed corporate governance and transparent regulatory reports. The company should have in place a policy regarding shareholders' rights, showing, among others, how the shareholders will be kept informed about operations and other developments, but also offering them opportunities to regularly discuss with the Board. Staff should be encouraged to share in the company success by ownership of shares.

\section{Stakeholder: employees}

CSR Business practices: It can include compliance with the law of the country and the development and implementation of its own business standards by involving all employees. The initiatives can involve the promotion of: work-life balance; flexible working structures; encouragement of personal developments by expanding skills; partnerships with schools/ organizations to develop training programs for employees; trainings and practical development programs; formal learning integrated into working day; career advancement opportunities; appraisal systems; encouraging dialogue; regularly monitoring employees' health; good occupational health; providing all employees with information on possible health risks and proper training if necessary; assessment and audit of health programs; 
providing education on health, on occupational safety, plans and preventative health and wellness program for employees and their families; making available the necessary safety equipment and training for proper use; performing specific studies of occupational safety hazards; offering orientation program for new employees; retirement and pre-retirement courses; providing educational opportunities for its employees' families; offering environmentally friendly and functional workplace; participating in volunteering activities; engaging employees through open-doorpolicy; employee consultations, meetings, surveys regarding their satisfaction related to pay and benefits received; respecting the right of free association; promoting gender equality and empowerment of women; providing information about internal diversity and inclusion; recruiting opportunities for a diverse workforce no matter of gender, age, ethnicities and background; establishing goals and objectives to improve diversity and inclusion; trainings for equal opportunities, diversity, inclusion and non-discrimination; formal policies and mechanisms for employees to report concerns, suggestions or criticism; offering a specific program for pregnant and flexible working schedules for breastfeeding, in accordance with the law, but also improvement of the maternal/ parental conditions.

\section{Stakeholder: customers}

CSR Business practices: Companies in the energy sector should consider and report on aspects of health and safety concerning its products and services. Certified and safe products, materials and technologies should be used. The companies should operate transparently. Customers should be aware of the energy they use, how it is produced and the impact it generates. A customer policy should be considered and made publicly available. The companies should promote safety and responsible consumption through education and information and empower customers to manage their energy use, footprint and costs. Free of charge energy evaluations/ audits and personalized energy efficiency recommendations should be provided in order for customers to lower their bills. They should be kept up-to-date by the company on the latest national information and global energy challenges, technologies, policies, etc. Multiple channels should be used to inform consumers and consider people with disabilities. Traditional communication channels should be kept, as well as the possibility for customers to access a wide range of payments options. Customers in need should be helped by providing them with relevant, sufficient, reliable and timely advice and arrangements, also have programs in place for those who voluntarily want to help the ones in need. Companies in the energy sector should carry out studies to measure the satisfaction levels of consumers and make improvements where necessary. They should get more involved with customers. When consumers want to take control of their own energy generation and usage, they should be provided with assistance and even technology. Companies should have the obligation to invest in an energy mix with targets settled for each year.

Stakeholder: suppliers/ contractors/ subcontractors

CSR Business practices: Companies should have in place a procedure for contractors' selection and management setting out expectations and requirements. Contractors are to be differentiated as: non fuel and fuel suppliers, as well as service providers. The contractors' capacity to comply with the requirements should be assessed. Those who undertake work on the company's behalf should comply with the company's codes but also meet anti-bribery and corruption requirements, policies and practices, as well as comply with the company's ethical, social, labour, safety, environmental and quality standards. Child labour regulations, nondiscrimination, gender equality criteria, antiharassment, forced or compulsory labour norms, freedom of association and collective bargaining, appropriate working conditions, landowners' rights should all be guaranteed by the contractors. The company can require or provide the necessary training programs for contractors' and sub-contractors' employees in order for those to meet 
requirements. The contractors' performances should be regularly monitored and checked. Results obtained after contractors' audits should be used in evaluation. The company should provide contractors with advice and guidance on its expectations. Businesses in host particular communities should have the opportunity to become the company's suppliers. Also, this opportunity should be available for individuals that generate income for excluded groups. The company should have in place formal procedures for penalizing infringements of its expectations and requirements.

\section{Stakeholder: community}

CSR Business practices: Any company in the energy sector should apply the best practices regarding nearby population, landowners and host community and be aware of the fact that company operations could affect them and consider they are one of the most important stakeholders. Any negative impact on them should be minimized to zero. Negative impact could be caused by: waste, odour, noise, deforestation, intense traffic, spilled pollutants, atmospheric emissions, dust on the roads, facilities which occupy private lands of landowners in the immediate vicinity, etc. Formal acceptance of nearby population and landowners for every new project, especially those who have belonged for generations to that host community, should be considered. The companies should actively engage in public consultations in order to carry out periodic reviews and assessments of the issues and risks of the host communities where they operate and search together for solutions, recognizing local characteristics and conditions and establishing plans that suit them best. NGOs should be invited in discussions. Formal evidence of these consultations should be offered. The mere participation of key local representatives should not be sufficient in planning and decision making. Multiple channels should be used to keep neighbours informed about company activities. Mechanisms should be put in place for the nearby population, landowners and host community to raise queries or concerns. Professional training, internship and jobs opportunities for unemployed youth should be provided, but also women and socially disadvantaged and/or vulnerable people should be considered by companies operating in energy sector. By offering mentoring with companies' own employees, they will be given the opportunity to use their specialized knowledge, skills and competencies. The companies could not be considered corporate citizens, they have no such rights (Matten and Crane, 2003), but should assume their responsibilities for the impact they generate. In case the company records a negative impact, plans and solutions should be in place and stakeholders should be informed before the negative event takes place. It should educate nearby population, landowners and host communities about health, biodiversity, energy conservation and safety, clean transport, clean production technologies and green energy. The companies should offer trainings to the host communities, including those vulnerable and/ or socially disadvantaged, to start up their own economic activities or cooperatives in order to became a contractor or a supplier. It should release information on the number and value of the contracts placed for host communities or about the number of people from those communities involved in research and innovative initiatives that advance clean energy production. The companies should also report donations made consisting of time, money, products, equipment, facilities, other non-monetary resources and, report separately the management costs of each host community. It should encourage employees to volunteer and contribute to the host communities. Equip nearby sites with devices offering to all interested people real time information regarding values of the pollutants measured in nearby stations, or slag and ash pits.

Present and future companies in the energy sector should get involved in partnerships with host communities and respect their rights and interests. Purchasing locally, promoting transparency, health, biodiversity, energy conservation and safety, clean transport, clean production technologies and green energy, running professional education 
and trainings in the energy field, creating jobs, improving energy local services, minimizing environmental impact to zero are all aspects which every company in the energy sector should address.

\section{Stakeholder: environment}

CSR Business practice: Companies in the energy sector should ensure compliance with environmental laws and regulations, international standards and voluntary commitments and should require contractors and sub-contractors to meet the environmental requirements and standards by which they operate. Environmental principles should be established and applied. The companies should have in place policies and plans for: environment, greenhouse gas, biomass, conservation of biodiversity, procurement of efficient energy and clean products, etc. They should conduct environmental impact assessments. Environmental information should be known by all employees of the company. Environmental impact should be identified as early as possible, prevented, eliminated or minimized to near zero. The companies should engage for environmental issues with their own stakeholders taking into consideration that participation of the nearby populations, landowners and host communities should be considered. Environmental policy and values should be communicated to company's stakeholders. Engagement with stakeholders should be documented. All employees should be trained regularly to deal with environmental issues. The companies should respond promptly to environmental incidents and have in place an environmental emergency plan. It should also design, construct, operate and maintain facilities in an environmentally sound and responsible manner, lowering company's own energy consumption, protecting biodiversity conservation and minimizing the footprint to zero. The land of the companies should be used to benefit wildlife. The companies should make assessments for the biodiversity of the area in which they operate and involve experts, NGOs, governmental and environmental entities but also nearby population and landowners in the immediate vicinity. Innovative building technologies should be developed. The companies are expected to inform on the development and investment in modernizing facilities, continuously educate the host communities on environmental issues and sustainable consumption, reforest the used lands with native trees and offer public education regarding tree care practices. The growth of the new forests should be monitored. The companies should offer support through sponsorships to environmental stewardship efforts, report the company's environmental impacts every year for each host community, as well as report about: the total number of spills to the environment; the total spilled volume; the chemicals used, the applicable national regulation regarding the used chemicals, as well as the chemicals released into the air, land and water; non-compliance with environmental laws and regulations; the non-compliances reported; monetary sanctions; the number of non-monetary sanctions; the number of environmental impact grievances; monetary environmental protection expenditure and investment. The companies should have spills response plans and take into consideration emergency situations, inform about the plans and seek stakeholder's feedback. The companies should also report on every geographical location and on: its type of operation, the areas impacted, risks identified and monitored, who and how is regularly monitoring the operations, what international instruments have been followed and how all the facts can be supported. They should source locally, from host communities when possible, and include climate change in decision making, provide information regarding where the fuels come from and to what extent they are generated from renewable sources, conduct and support environmental education research on flora and fauna nearby the area where the company operates. Other actions should include support of research on alternative vehicles and new green technologies, as well as raising public awareness, reporting on total research and development expenditures, but also on the partners involved. Energy production should be sustainable and clean and for this purpose environmentally friendly technology solutions 
should be used. Forests and plant crops used in the energy production should come from sources that are managed sustainably, with the possibility to prove it. Mortality monitoring should be conducted formally and implementation of voluntary standards should be considered. CSR activities in the environmental field exceed what is required by law and may also involve activities such as measurement, recording, reporting and reduction of emissions, water, energy, waste, garbage. A management emissions (GHGs) plan should be in place. Sources of Greenhouse Gas emissions are: carbon dioxide $\left(\mathrm{CO}_{2}\right)$; methane $\left(\mathrm{CH}_{4}\right)$; nitrogen dioxide $\left(\mathrm{NO}_{\mathrm{x}}\right)$; sulphur dioxide $\left(\mathrm{SO}_{2}\right)$; volatile organic carbon (VOCs), water vapours, etc. The companies should manage and report the GHGs emitted during activities. There are direct GHG emissions which occur from sources that are owned or controlled by the company, named scope 1 emissions. There are indirect GHG emissions from the generation of purchased electricity consumed by the company (scope 2 emissions) and emissions which occur from sources not owned or controlled by the company, like for example from travelling (scope 3 emissions). Every year, companies should report to stakeholders detailed information regarding scope 1 , scope 2 and scope 3 emissions and indicate the sources of the energy used. The companies should manage all the environmental impact and explain how it will address it. Noise, dust and increased road usage are some of the forms this impact may take. Conduct a water management plan which can be extended to the entire value chain, in order to conserve potable water resources by innovative solutions. Monitor and release by reporting, each year and for each area of operation, information regarding the sources of water used, the quantity of freshwater consumption across the organization, resulted waste water, used non-potable water, re-used water and how much of it was disposed back to the environment as fresh water. The points where the companies release waste water should be monitored and environmental impact should be addressed and reported to stakeholders. The companies should protect the quality of fresh water of the host community, retain an independent third party environmental audit to conduct assurance, conduct a waste management plan in line with internationally accepted best practices and legal requirements. They should disclose information on total hazardous and nonhazardous waste using measurement, on the methods by which the waste is dispersed and how much of it is: reused, recycled, composted, incinerated, stored on landfill, etc. They should also make public information regarding the certified waste services used to treat hazardous and non-hazardous waste, what and how much it is recycled, for example: paper, cardboard, wood, metal, etc. The companies are also expected to educate stakeholders to prevent pollution by reducing the generation of waste.

\section{Concluding Remarks}

The author tried to describe how CSR is practiced starting from the industry information of the analysed region. As the main research method applied in this article is the survey of the sampled companies on the basis of information provided in their websites or reports, the reliability of information posted cannot be guaranteed as it is unregulated and discretionary. Previous research was conducted on Romanian SOCs (Buturoagă, 2016) but also on private Romanian companies (Buturoagă, 2014) and there were difficulties to have access to companies and their day-to-day CSR activities, even those conducted as the national law required. More empirical studies should explore CSR implementation in companies, in developing countries and in specific sectors by investigating how, when and under which conditions stakeholders are considered, especially the particular community, the nearby population and landowners where the company operates. The investigated sample is representative for the South-West Oltenia Development Region, one of the eight development regions of the country. The premise of this article consists in acquiring practical evidence and making suggestions for stakeholder approach in a specific national and regional context with its unique requirements. The results can be used in 
research on developing or emerging economies.

The author considers to have tried to answer, through identified results, the question that generated this study, so only 4 out of 6 main companies which operate in the energy sector of South-West Oltenia Development Region have, on their website, a CSR dedicated section and only 3 of them offer information. CSR is defined by only two companies. Regarding the standards implemented by companies: 5 have ISO 9001; ISO 14001; OHSAS 18001 and 1 company has only ISO 9001; ISO 14001. Company $\mathrm{F}$ has in addition other standards. Key stakeholders were identified by only 1 company and were presented alphabetically. Gender is taken into consideration by only 1 company out of 6 analysed. Health received attention from 3 companies and education by 4 of them, but the generated impact cannot be assessed on the level of the analysed region as long as the companies do not provide timely and detailed information for each location where they operate. Generalization regarding the way corporate social responsibility is approached in Romanian companies in the energy sector can be applied to SOCs that do not seem to understand CSR and consider it equivalent with philanthropy. Moreover, mandatory activities are considered by state owned companies as CSR actions. Corporate social responsibility actions of private companies from South-West Oltenia Development Region are better than those of SOCs. CSR actions of the Romanian companies operating in the energy sector seem to change according to some national factors. SOCs offer on their websites only few and/ or outdated CSR information, which could be caused by the fact that they even still operate in a protected environment, are profit-based domestic companies and, recently, financially let to assume this role. On the contrary, CSR of analysed private companies continues to grow in scale and sophistication. This could be due to the need to raise image, reputation or demand conditions, facts that will raise sales, and implicitly market share and profit, and/or out of ethical motivation. Stakeholders were engaged only by company $\mathrm{F}$, the one that also identified them, and problems arose in discussions regarding community stakeholder, which was neither involved in the dialogue with the company held in 2014, nor in the consultation and materiality analysis, in 2014. Another discussion regarded company F's initiative to set up, in some cases, only with its financial support local NGOs in host communities where the company operates. The author considers this kind of action to further weaken confidence of host communities. It is also appreciated that for companies operating in the energy sector the host communities, population and landowners which neighbour the companies' operations should represent a key stakeholder and should be consulted and involved. Through the results obtained there are information indicating that some companies still support the perpetuation of circumstances that generate injustice (by offering sponsorships to orthodox places of worship and in this way discriminating under represented people belonging to religious minorities from host communities; injustice towards women to which only 1 company addressed through its diversity policy, towards people who have belonged for generations to the host communities in which companies operate and towards ethnic minorities, as there is no available information about their identification and engagement in discussions, except for one company). Another conclusion is that in assessing the impact of CSR actions, more emphasis should be put on the process (Crane et al, 2014: 312). The companies' CSR activities should be correlated to the business internal core competences and the company's core mission and strategy (Vaidyanathan et al, 2008). An annual report should also be considered for publication in an online format by those who failed to report. This company behaviour could speak about a State that tends not to be stakeholder oriented. Moreover, this national characteristic is not overridden by companies operating in a risk sector, the energy sector. International voluntary initiatives could be used to prepare the report as for reasons of efficiency and for a common understanding of it (ex: Global Reporting Initiative G4, which offers two options for preparing a report: the CORE option and the COMPREHENSIVE option 
according to the reporting needs of the organization; United Nations Global Compact; Accountability's AA 1000 APS, etc.). Reporting will help improve transparency and credibility and benefit from stakeholders' appreciation, fact that can reward the CSR efforts. The results obtained through this research also speak about the existence of a heterogeneity regarding the behaviour of the companies operating in the South-West Oltenia Development Region. In Romania, CSR is left to corporations' decision and selfregulation of companies is not always functional, but also on an international level there are only voluntary standards no for the consideration of varying stakeholders' interests (Reed, 2002) to be adopted by companies and CSR is voluntarily integrated and information presented discretionary. As we can see from the obtained results, stakeholders are very often unidentified and unengaged by companies, so the rights of later generations or collective rights of minorities and people who have belonged for generations to that particular host community are not prioritized as companies prioritize economic aspects. Moreover, the stakeholder theory is supported through the theory of property rights (Donaldson and Preston, 1995:88). On a national level, there is no obligation to obtain permission from the host community or even from the ones who neighbour companies in order to operate and extend operations, even if companies are not citizens and have no such rights. Also, Romanian' cultural values emphasize on the acceptance of unequally distributed power (Brancu et al., 2015). All this led up to the solution that companies should respect different stakeholders' interests and honour ethical values. Society important issues shouldn't be left to corporations' decision, but should be legally regulated (Crane et al, 2014). When the State fails to take measures, then corporations should adopt selfregulation (Reed, 2002), which may provide opportunities for innovation. Greater attention should be given by companies to concerns regarding ethical and environmental issues. Romanian CSR energy companies' challenges are: CSR strategic development, where companies could bring their own expertise; stakeholders' identification and involvement; measurement of the current specific targets, which should be focused on social impact and reporting. Traditional old energy sources affect water, air, soil and subsoil with effect on biodiversity. With the increasing number of small energy producers, competition will also increase, encouraging competitiveness, and the price will be more affordable, in the future, for consumers who will have the opportunity to choose with whom to partner. It is important in this regard for current and future producers to integrate CSR and to engage with their stakeholders, as it is appreciated that the firm's conventional financial performance is influenced by the firm's positive relationships with its stakeholders (Ogden and Watson, 1999; Berman et al, 1999:503), leading to shareholder wealth (Hillman and Keim, 2001).

\section{References}

1. Aguilera, RV., Williams, CA., Conley, JM. and Rupp, DE. (2006), 'Corporate governance and social responsibility: a comparative analysis of the UK and the US,' Corporate Governance: An International Review; 14 (3):147-158.

2. Baleanu, TE., Chelcea, L. and Stancu, A. (2011), 'The social responsibility of the top 100 Romanian companies. An analisys of corporate websites,' Amfiteatru Economic, 13 (29):235-248.

3. Berman, SL., Wicks, AC., Kotha, S. and Jones, TM. (1999), 'Does stakeholder orientation matter? The relationship between stakeholder management models and firm financial performance,' The Academy of Management Journal, 42 (5): 488-506.

4. Bird, R., Hall, A. D., Momentè, F. and Reggiani, F. (2007), 'What corporate social responsibility activities are valued by the market,' Journal of Business Ethics, 76 (2), 189-106.

5. BP. (2015). BP Statistical Review of World Energy. [Online] Pureprint Group Limited, UK; [Accessed 2016 January 13]. Available from https://www.bp.com/content/dam/bp/pdf/e 
nergy-economics/statistical-review-2015/bpstatistical-review-of-world-energy-2015-fullreport.pdf

6. Buturoaga, CM. (2016), 'CSR of stateowned companies in a European developing country - the case of Romania,' Journal of Organizational Management Studies, vol. 2016 (2016), Article ID 934180, DOI: 10.5171/2016. 934180

7. Buturoaga, CM. (2014), 'Motivations and benefits of social responsibility - The case of Romania,' Proceedings of the $7^{\text {th }}$ International Management Conference, "Managerial challenges of the contemporary society" (MCCS), ISSN: 2069-4229, 6-7 June 2014, ClujNapoca, Romania, 52-58.

8. Carroll, AB. and Buchholtz, AK. (2012), Business \& society: ethics, and stakeholder management. $8^{\text {th }}$ ed., USA: Cengage Learning.

9. Carroll, AB. 2008, A history of corporate social responsibility: concepts and practices. In A. Crane, A. McWilliams, D. Matten, J. Moon \& D. S. Siegel (Eds.). The Oxford handbook of corporate social responsibility. United States: Oxford University Press, p. 19-46.

10.Chaudhri, V. and Wang, J. (2007), 'Communicating Corporate Social Responsibility on the Internet: A Case Study of the Top 100 Information Technology Companies in India,' Management Communication Quarterly, 21 (2): 232-247.

11.Clarkson, Max BE. (1995), 'A stakeholder framework for analyzing and evaluating corporate social performance,' The Academy of Management Review, 20 (1): 92-117.

12.Coombs, WT. and Holladay, SJ. (2011), Managing corporate social responsibility: A communication approach. USA: Wiley Blackwelt.

13.Córdoba-Pachón, JR., Garde-Sánchez, R. and Rodríguez-Bolívar, MP. (2014), 'A Systematic view of corporate social responsibility (CSR) in state-owned enterprises (SOEs),' Knowledge and Process Management, 21 (3): 206-219.

14.Crane, A., Matten, D. and Spence, LJ. (2014), Corporate social responsibility: readings and cases in a global context. $2^{\text {nd }}$ ed., USA: Routledge.

15. Dahlshrud A. (2008), 'How corporate social responsibility is defined: an analysis of 37 definitions,' Corporate Social Responsibility and Environmental Management, 15: 1-13. DOI: $10.1002 /$ csr.132

16.Danilet, M. and Mihai, O. (2012). CSR online discourse practices in the Romanian energy sector, [Online]. Journal of Eastern Europe Research in Business \& Economics, [Accessed 2015 February 22], Available: http://dx.doi.org/:10.5171/2013.725039

17.Decker, OS. (2004), 'Corporate social responsibility and structural change in financial services,' Managerial Auditing Journal, 19 (6): 712-728.

18.Deva S. (2006), 'A critique of the U.N.'s "public-private" partnership for promoting corporate citizenship", Syracuse Journal of International Law and Commerce, 34(1): 107151.

19.Donaldson, T. and Preston, LE. (1995), 'The stakeholder theory of the corporation: concepts, evidence, and implications,' Academy of Management Review, 20 (1): 6591.

20.Dura, C. and Dobre Baron, O. (2015), 'Bune practici in responsabilitatea sociala corporative din Romania: Strategia Petrom OMV,' Calitatea-acces la success, 16 (149): 1725.

21.European Commission. 2015a. A Framework Strategy for a Resilient Energy Union with a Forward-Looking Climate Change Policy. [Online]. Brussels, COM (2015) 80 final, [Accessed 2015 November 13]. Available:http://eur-

lex.europa.eu/resource.html?uri=cellar: $1 \mathrm{bd} 46$ c90-bdd4-11e4-bbe1-

01aa75ed71a1.0001.03/DOC_1\&format=PDF 
22.European Commision. 2015b. Innovation Union Scoreboard [Online]. Belgium. [Accessed 2016 January 20]. Available: http://www.urenio.org/el/wp-

content/uploads/2015/10/1.2.-Innovation-

Union-Scoreboard-2015.pdf

23.European Commission. 2014. A policy framework for climate and energy in the period from 2020 up to 2030, SWD (2014) 15 final. [Online]. [Accessed 2016 January 20]. Available: http://eur-lex.europa.eu/legalcontent/EN/TXT/PDF/?uri=CELEX:52014SC0 015\&from $=\mathrm{EN}$

24.European Commission. 2012. Energy 2050 Roadmap, [Online]. Luxembourg. [Accessed 2015 November 03]. Available: https://ec.europa.eu/energy/sites/ener/files /documents/2012_energy_roadmap_2050_en _0.pdf

25.European Communities. 2001. Green Paper: Promoting a European framework for corporate social responsibility. [Online]. [Accessed 2015 November 06]. Available: http://europa.eu/rapid/press-release_DOC01-9_en.pdf

26.EY. 2015. Talent at the table: Women in power and utilities index 2015. [Online]. [Accessed 2016 January 20]. Available: http://www.ey.com/Publication/vwLUAssets /EY-women-in-power-and-utilities-index2015/\$FILE/EY-women-in-power-andutilities-index-2015.pdf

27.EY. 2014. Renewable energy country attractiveness index, issue 40. [Online]. [Accessed 2015 December 27]. Available: http://www.ey.com/Publication/vwLUAssets /EY_-

_Renewable_energy_country_attractiveness_in dex_-_February_2014/\$FILE/EY-recai-issue40-february-2014.pdf

28.Freeman, RE. (1984), Strategic Management: A Stakeholder Approach. Boston: Pitman.

29.Freeman, R.E. (1999), 'Divergent stakeholder theory', Academy of Management Review, 24(2), 233-236.
30.Freeman, RE., Andrew, C. and Wicks, BP. (2004), 'Stakeholder Theory and "The Corporate Objective Revisited",' Organization Science, $\quad 15 \quad$ (3):364-369. http://dx.doi.org/10.1287/orsc.1040.0066

31.Frisko, D. (2012), 'Exploring potential power of corporate social responsibility toward sustainability development: analysis of state-owned company social responsibility in Indonesia,' Int. J. Sustainable Strategic Management, 3 (3): 205-220.

32.Galbreath, J. (2006), 'Corporate social responsibility strategy: strategic options, global consideration,' Corporate Governance, 6 (2): 175-187.

33.Gavrilescu, E., Buzatu, GD. and Popescu, SM. (2013), 'Air pollution by particulate matter $\left(\mathrm{PM}_{10}\right)$ in Craiova Municipality,' Bulletin UASMV Agriculture series, 70 (2): 439440.

34.Georgescu, MA. and Herman, E. (2014), 'Social corporate responsibility regarding household consumer satisfaction with the electric power supply services,' Amfiteatru Economic, 16 (35): 123-137.

35.Gond, JP., Kang, N. and Moon, J. (2011), 'The government of self-regulation: on the comparative dynamics of corporate social responsibility,' Economy and Society, 40 (4): 640-671.

36.International Energy Agency. 2015a. World Energy Outlook. [Online].[Accessed 2015 December 27]. Available: http://www.worldenergyoutlook.org/resourc es/energydevelopment/energyaccessdatabas e/

37. International Energy Agency. 2015b. Energy and Climate Change: World Energy Outlook Special Report. [Online]. [Accessed 2015 December 27]. Available: https://www.iea.org/publications/freepublicat ions/publication/WEO2015SpecialReportonEn ergyandClimateChange.pdf

38. International Energy Agency. 2014. World Energy Outlook, OECD/IEA 2014. [Online]. 
[Accessed 2015 December 13]. Available: http://www.iea.org/textbase/npsum/weo20 14sum.pdf

39.Jamali, D. 2008, 'A stakeholder approach to corporate social responsibility: A fresh perspective into theory and practice,' Journal of Business Ethics, 82 (1):213-231.

40.Lungu, C., Dascalu, C., Caraiani, C. and Balea, EC. (2014), 'Economic approach of the scenarios regarding the impact of the consumer's empowerment and companies' responsibility for environment sustainability on the electricity market performance,' Amfiteatru Economic, 16 (35): 187-200.

41.Healy, P., Hutton, AP., Palepu, KG. (1999), 'Stock Performance and Intermediation Changes Surrounding Sustained Increases in Disclosure,' Contemporary Accounting Research, 16 (3): 485-520.

42.Hillman, AJ., Keim, GD. (2001), 'Shareholder Value, Stakeholder Management, and Social Issues: What's the Bottom Line?' Strategic Management Journal, 22 (2): 125139.

43.Hori S., Shinozaki M., Nogata D. and Fujita T. (2014), 'The role of CSR in promoting companies' energy-saving actions in two Asian cities', Energy Policy, 69(C): 116-121.

44.Hulme, D., Savoia, A., Sen, K. (2015), 'Governance as a Global Development Goal? Setting, Measuring and Monitoring the Post2015 Development Agenda,' Global Policy, 6 (2): 85-96.

45.Ioannou, I. and Serafeim, G. (2015), 'The impact of corporate social responsibility on investment recommendations: Analysts' perceptions and shifting institutional logics,' Strat. Mgmt. J., 36:1053-1081. doi:10.1002/smj.2268

46.Lyon, TP., Maxwell, JW. (2006). Greenwash: corporate environmental disclosure under threat of audit. Working Paper, University of Michigan. [Online]. Stephen M. Ross School of Business, [Accessed $2015 \quad$ October 2]. Available: http://kelley.iu.edu/riharbau/repec/iuk/wpa per/bepp2006-07-lyon-maxwell.pdf

47.Mandl, I. and Dorr, A. (2007). CSR and Competitiveness European SMEs' good practice - consolidated European report. [Online]. KMU FORSCHUNG Austria - Austrian Institute for SME Research. [Accessed 2015 December 27]. Available: http://www.bsocial.gva.es/documents/6107 67/716777/CSR_competitiveness_european.p df/64db87c9-3062-4e76-bcbf-bc1bcace91b3

48. Matten, D. and Crane, A. (2003). Corporate citizenship: Towards an extended theoretical conceptualization. [Online]. International Centre for Corporate Social Responsibility (ICCSR). Research Paper Series-ISSN 14795124 2003. [Accessed 2015 December 27]. Available:

http://www.nottingham.ac.uk/business/ICCS R/assets/researchpapers/04-2003.PDF

49. Mazurkiewicz, P. (2004). Corporate environmental responsibility: Is a common CSR framework possible? [Online]. [Accessed 2015 January 22]. Available: http://go.worldbank.org/RDYD5ZU9P0

50.Mezher, T., Tabbara S. and Al-Hosany N. (2010), 'An overview of CSR in the renewable energy sector: Examples from the Masdar Initiative in Abu Dhabi', Management of Environmental Quality: An International Journal, 21(6):744-760.

51.Mitchell, RK., Agle, BR. and Wood DJ. (1997), 'Toward a theory of stakeholder identification and salience: defining the principle of who and what really counts,' The Academy of Management Review. 22 (4): 853886.

52.Moon, J. and Shen, X. (2010), 'CSR in China Research: Salience, Focus and Nature,' Journal of Business Ethics, 94 (4): 613-629.

53. Moon, J. (2004). Government as a driver of corporate social responsibility. [Online]. International Centre for Corporate Social Responsibility (ICCSR), Research Paper Series - ISSN 1479-5124. [Accessed 2015 December 17]. Available: 
54.https://www.nottingham.ac.uk/business/I CCSR/assets/researchpapers/20-2004.pdf

55.Monks, R. and Minow, N. (2004), Corporate Governance. 3rd ed. Boston. MA: Blackwell Publishing.

56.OECD (The Organisation for Economic Cooperation and Development). 2015. OECD guidelines on corporate governance of stateowned enterprises. [Online]. [Accessed 2015 September 01]. Available: http://www.oecd.org/daf/ca/OECDGuidelines-Corporate-Governance-SOEs2015.pdf

57.Ogden, S. and Watson, R. (1999), 'Corporate performance and stakeholder management: balancing shareholder and customer interests in the U.K. privatized water industry,' Academy of Management Journal, 42 (5): 526-538.

58.Sethi, SP. (2003), 'Globalization and the good corporation: a need for proactive coexistence,' Journal of Business Ethics, 43 (1-2): 21-31.

59.Smith, NC. (2003), 'Corporate social responsibility: whether or how?' California Management Review, 45 (4): 52-76.

60.South-West Oltenia Regional Development Agency. 2014. S-W Oltenia plan for regional development 2014-2020, p. 1-640. [Online]. [Accessed 2015 November 20]. Available: http://www.adroltenia.ro/planul-dedezvoltare-regionala-2014-2020/

61.Spiller, R. (2000), 'Ethical business and investment: a model for business and society,' Journal of Business Ethics, 27: 149-160.

62.The National Standardization Body (ASRO). 2011. SR ISO 26000:2011. Linii directoare privind responsabilitatea sociala. ASRO. Bucharest.

63.Transparency International. 2015. [Online]. [Accessed 2016 January 07]. Available:

https://transparency.org/cpi/2015
64.Peng, MW. and Pleggenkuhle-Miles, EG. (2009), 'Current debates in global strategy,' International Journal of Management Reviews, 11(1): 51-68.

65.Pollack, MA. and Hafner-Burton, E. (2000), 'Mainstreaming Gender in the European Union,' Journal of European Public Policy, Special issue on Women, Power and Public Policy, 7(3): 432-56.

66.Porter, ME. and Kramer, MR. (2002). The competitive advantage of corporate philanthropy. [Online]. Harvard Business Review. [Accessed 2015 September 03]. Available:

https://sharedvalue.org/sites/default/files/r esource-files/Competitive_Advantage.pdf

67.Prayogo, D. (2013), 'Measuring Corporate Social Responsibility for Local Communities in Mining, Oil and Gas Industries, the Case of Indonesia,' Journal of Economics and Sustainable Development, 4 (1), 59-68.

68. Ranängen, H. and Zobel, T. (2014), 'Revisiting the 'how' of corporate social responsibility in extractive industries and forestry,' Journal of Cleaner Production, 84 (1): 299-312.

69. Reed, D. (2002), 'Employing normative stakeholder theory in developing countries a critical theory perspective,' Business \& Society, 41(2): 166-207.

70.REN21. 2014. Renewables 2014 Global Status Report. [Online]. [Accessed 2015 November 13]. Available: http://www.ren21.net/Portals/0/documents /Resources/GSR/2014/GSR2014_full\%20rep ort_low\%20res.pdf

71. Romanian Department for Energy. 2014. Romanian Energetic Strategy, draft for public debate. [Online]. [Accessed 2015 November 01]. Available: http://www.econetromania.com/files/document-2014-12-518755546-0-strategia-energetica-analizastadiului-actual.pdf

72. Romanian Government. 2011. Strategia Naţională a României de Promovare a 
Responsabilității Sociale 2011-2016 (Romanian Strategy for the promotion of Social Responsibility 2011-2016). Bucharest. [Online]. [Accessed 2015 October 11]. Available: http://www.sgg.ro/docs/File/UPP/doc/strat egia_nationala_\%20de_promovare_a_responsa bilitatii_sociale_2011_2016.pdf

73.Romanian National News Agency. 2014. [Online]. [Accessed 2016 February 15]. Available:

http://www.agerpres.ro/economie/2014/09 /18/bm-romania-are-un-rol-important-inreducerea-emisiilor-de-gaze-cu-efect-de-sera14-02-55

74.Romanian Agency for Environment Protection - APM Dolj. Environment Agreement. [Online]. [Accessed 2016 January 13]. Available: http://apmdj.anpm.ro/anpm_resources/migr ated_content/uploads/108900_Proiect\%20A M_Suprainaltare\%20depozit\%20cenusa_CET \%20II\%20Craiova.pdf; http://www.anpm.ro/documents/19431/475 2169/Proiect+AIM-

2016+S+CEO+SE+Craiova+II.pdf/dc00003fb75d-495b-9cc4-e38db076ede6?version=1.0

75.Steurer, R. (2010), 'The role of governments in corporate social responsibility: Characterising public policies on CSR in Europe,' Policy Sciences, 43 (1): 4972.

76.United Nations. 2015a. World Population Prospects, Revision, [Online]. New York. [Accessed 2016 January 23]. Available: http://esa.un.org/unpd/wpp/publications/fil es/key_findings_wpp_2015.pdf

77.United Nations. 2015b. The millennium development goals report. [Online]. New York. [Accessed 2016 January 23]. Available: http://www.un.org/millenniumgoals/2015_ MDG_Report/pdf/MDG\%202015\%20rev\%20 (July\%201).pdf

78.Vaidyanathan, B. (2008). Corporate Giving: A Literature Review. Research report for the Science of Generosity Project. [Online]. [Accessed 2015 March 12]. Available: https://generosityresearch.nd.edu/assets/17 636/corporate_giving_final.pdf

79.Van Marrewijk, M. (2003), 'Concepts and Definitions of CSR and Corporate Sustainability: Between Agency and Communication,' Journal of Business Ethics, 44 (2), 95-105.

80.Visser, W. (2013), The age of responsibility CSR 2.0 and the New DNA of Business. United Kingdom: John Wiley \& Sons Ltd.

81.Visser, W. (2008), Corporate social responsibility in developing countries, In: Crane A, McWilliams A, Matten D, Moon J, Siegel D. editors. The Oxford handbook of Corporate Social Responsibility, Oxford: Oxford University Press, p. 473-479.

82.Wood, DJ. (1991), 'Corporate social performance revisited,' Academy of Management Review, 16:691-718.

83.World Health Organization. 2006. Fuel for Life. Household Energy and Health. [Online]. [Accessed 2015 November 12]. Available: http://www.who.int/indoorair/publications/ fuelforlife.pdf

84.World Commission on Environment and Development. 1987. Our common future. [Online]. United Nations. [Accessed 2015 November 03]. Available: http://conspect.nl/pdf/Our Common FutureBrundtland Report 1987.pdf

85.Werther, WB. and Chandler, JD. (2006), Strategic Corporate Social Responsibility: stakeholders in a global environment. London: SAGE Publications Ltd.

86.Zaharia, RM. and Grundey, D. (2011), Corporate social responsibility in the context of financial crisis: a comparison between Romania and Lithuania,' Amfiteatru Economic, 13 (29): 195-206. 